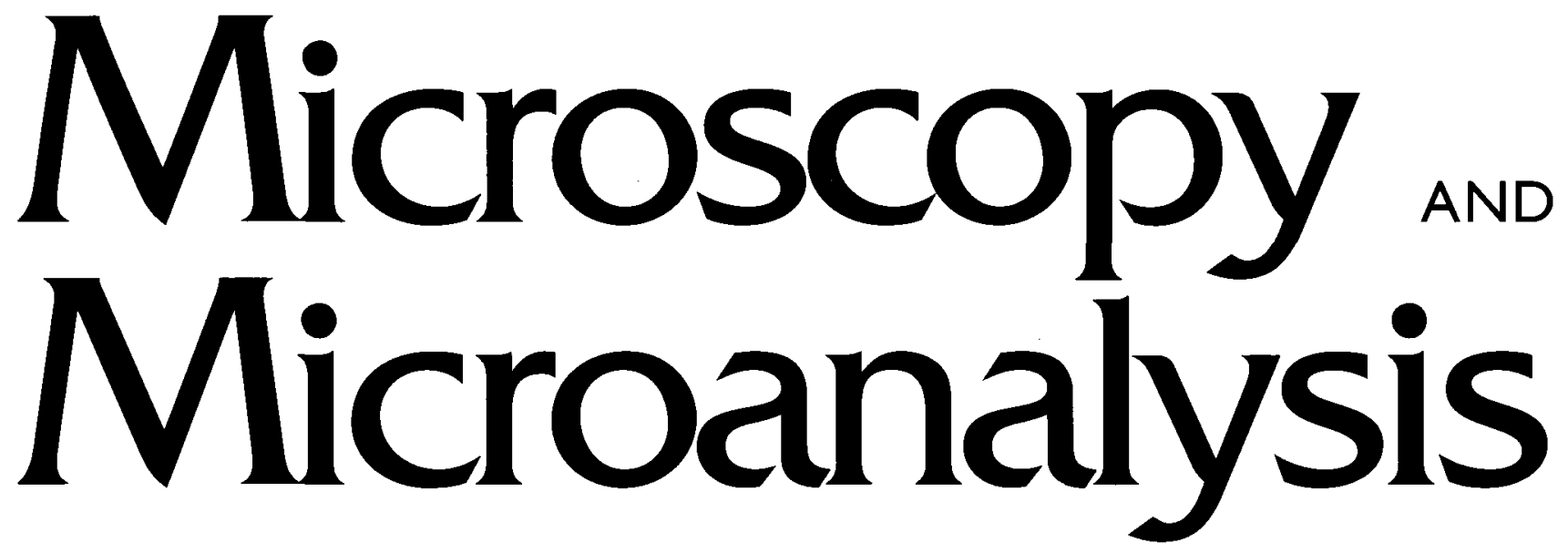

IHE OFFICIAL JOURNAL OF

MICROSCOPY SOCIETY OF AMERICA

MICROBEAM ANALYSIS SOCIETY

MICROSCOPICAL SOCIETY OF CANADA / SOCIÉTÉ DE

MICROSCOPIE DU CANADA

MEXICAN MICROSCOPY SOCIETY

BRAZILIAN SOCIETY FOR MICROSCOPY AND MICROANALYSIS

PUBLISHED IN AFFILIATION WITH

ROYAL MICROSCOPICAL SOCIETY

GERMAN SOCIETY FOR ELECTRON MICROSCOPY

BELGIAN SOCIETY FOR MICROSCOPY

MICROSCOPY SOCIETY OF SOUTHERN AFRICA

Editor in Chief

Editor, Electron and Scanning Probe

Microscopies

Dale E. Johnson

Graduate School

University of South Florida

4202 E. Fowler Avenue, FAO 126

Tampa, Florida 33620-7900

Editor, Biological Applications

A. Kent Christensen

Anatomy and Cell Biology

University of Michigan Medical School

Ann Arbor, Michigan 48109-0616

\section{Expo Editor}

William T. Gunning

Pathology Department

Medical College of Ohio

Toledo, Ohio
Editor, Computers and Image Analysis

Michael A. O'Keefe

Lawrence Berkeley Laboratory

Building 72

Berkeley, California 94720

Editor, Materials Applications

Ray W. Carpenter

Center for Solid State Science,

PSB-234

Arizona State University

Tempe, Arizona 85287-1704

News and Commentary Editor

Barbara Reine

Botany Department

University of Washington

Seattle, Washington
Editor, Microanalysis

Charles E. Lyman

Materials Science and Engineering

Lehigh University

5 East Packer Avenue

Bethlehem, Pennsylvania

18015-3195

Editor, Optical and Confocal Microscopy

P.C. Cheng

Advanced Microscopy and Imaging

Laboratory

Department of Electrical and

Computer Engineering

State University of New York at

Buffalo

Buffalo, New York 14260

\section{Proceedings Editor}

G. W. Bailey

Baton Rouge, Louisiana 


\section{Editorial Board}

James Bentley

Metals and Ceramics Division

Oak Ridge National Laboratory

Oak Ridge, Tennessee

Carlos Bustamente

Institute of Molecular Biology

University of Oregon

Eugene, Oregon

Patricia G. Calarco

Department of Anatomy

University of California

San Francisco, California

Jean-Pierre Chevalier

CECM-CNRS

Vitry, France

Wah Chiu

Department of Biochemistry

Baylor College of Medicine

Houston, Texas

John Cowley

Department of Physics and

Astronomy

Arizona State University

Tempe, Arizona

Alwyn Eades

Department of Materials

Science and Engineering

Lehigh University

Bethlehem, Pennsylvania

Ray Egerton

Physics Department

University of Alberta

Edmonton, Alberta, Canada

Mark H. Ellisman

Department of Neuroscience

School of Medicine

University of California

San Diego, California

O. Hayes Griffith

Institute of Molecular Biology

University of Oregon

Eugene, Oregon

Linn W. Hobbs

Massachusetts Institute of

Technology

Cambridge, Massachusetts
Colin Humphreys

University of Cambridge

Cambridge, United Kingdom

Sumio Iijima

NEC Corporation

Fundamental Research Labs

Tsukuba, Ibaraki, Japan

Michael Isaacson

Applied and Engineering Physics

Cornell University

Ithaca, New York

David Joy

EM Facility, Department of Zoology

University of Tennessee

Knoxville, Tennessee

Morris Karnovsky

Department of Pathology

Harvard Medical School

Boston, Massachusetts

Janos Kirz

SUNY Stony Brook

Stony Brook, New York

Paul Lauterbur

College of Medicine

University of Illinois at Urbana-

Champaign

Urbana, Illinois

Lee Makowski

Institute of Molecular Biophysics

Florida State University

Tallahassee, Florida

J. Richard McIntosh

Department of MCD Biology

University of Colorado

Boulder, Colorado

Ronald A. Milligan

Department of Cell Biology

Scripps Research Institute

La Jolla, California

F.P. Otensmeyer

Ontario Cancer Institute

Toronto, Canada

Giulio Pozzi

Department of Physics

University of Bologna

Bologna, Italy
Michael P. Sheetz

Department of Cell Biology

Duke University Medical Center

Durham, North Carolina

John Silcox

Applied and Engineering Physics

Cornell University

Ithaca, New York

Guillermo Solórzano

Department of Materials Science and Metallurgy

Catholic University of Rio de Janeiro

Rio de Janeiro, Brazil

Andrew P. Somlyo

Department of Physiology

School of Medicine

University of Virginia

Charlottesville, Virginia

Gareth Thomas

Department of Material Science and Engineering

University of California

Berkeley, California

James N. Turner

New York State Department of Health

Albany, New York

Dirk van Dyck

University of Antwerp

Antwerp, Belgium

Watt Webb

School of Applied Physics

Cornell University

Ithaca, New York

David B. Wittry

Department of Material Science

University of Southern California

Los Angeles, California

Nestor J. Zaluzec

Materials Science Division

Argonne National Laboratory

Argonne, Illinois

\section{Founding Editor}

Jean-Paul Revel

Division of Biology

California Institute of Technology

Pasadena, California 


\section{Aims and Scope}

Microscopy and Microanalysis provides the highest quality forum for publication of truly innovative results in a wide range of fields of importance to microscopy and microanalysis. To this end, the Journal publishes original research papers in the entire range of microscopy and microanalysis, from new methods and instrumentation to their application to compositional analysis for determination of structure or chemistry at the microscopical level. Fields of interest include: microbeam analysis, scanning probe microscopies, and all forms of light microscopy. Image acquisition and improvement techniques, along with computer-assisted microscopy, are included.

Four categories of communications are published in the Journal. Regular Articles contain reports of new instrumentation and new theoretical methods and their applications to microstructural analysis in a broad range of fields including biological, physical, and materials science. Communications are short technical or scientific articles in biological, physical, or materials science. Reviews have a broader technical content than Regular Articles. Letters to the Editor may be on any topic.

\section{Copyright Information}

Submission of a manuscript implies: that the work described has not been published before (except in the form of an abstract or as part of a published lecture, review, or thesis); that it is not under consideration for publication elsewhere; that its publication has been approved by all coauthors, if any, as well as by the responsible authorities at the institute where the work has been carried out; that, if and when the manuscript is accepted for publication, the authors agree to automatic transfer of the copyright to the Microscopy Society of America; that the manuscript will not be published elsewhere in any language without the consent of the copyright holders; and that written permission of the copyright holder is obtained by the authors for material used from other copyrighted sources.

All articles published in this journal are protected by copyright, which covers the exclusive rights to reproduce and distribute the article (e.g., as offprints), as well as all translation rights. No material published in this journal may be reproduced photographically or stored on microfilm, in electronic data bases, video disks, etc., without first obtaining written permission from the publisher.

The use of general descriptive names, trade names, trademarks, etc., in this publication, even if not specifically identified, does not imply that these names are not protected by the relevant laws and regulation.

While the advice and information in this journal is believed to be true and accurate at the date of its going to press, neither the authors, the editors, nor the publisher can accept any legal responsibility for any errors or omissions that may be made.

The publisher makes no warranty, express or implied, with respect to the material contained herein. Springer-Verlag publishes advertisements in this journal in reliance upon the responsibility of the advertiser to comply with all legal requirements relating to the marketing and sale of products or services advertised. Springer-Verlag and the editors are not responsible for claims made in the advertisements published in the journal. The appearance of advertisements in Springer-Verlag publications does not constitute endorsement, implied or intended, of the product advertised or claims made for it by the advertiser.

Authorization to photocopy items for internal or personal use, or the internal or personal use of specific clients, is granted by SpringerVerlag New York, Inc., provided that the appropriate fee is paid directly to Copyright Clearance Center, 222 Rosewood Drive, Danvers, MA 01923, USA (Tel: (508) 750-8400), stating the ISSN (1431-9276), the volume, and the first and last page numbers of each article copied. The copyright owner's consent does not include copying for general distribution, promotion, new works, or resale. In these cases, specific written permission must first be obtained from the publisher.

The Canada Institute for Scientific and Technical Information (CISTI) provides a comprehensive, world-wide document delivery service for all Springer-Verlag journals. For more information or to place an order for a copyright-cleared Springer-Verlag document, please contact Client Assistant, Document Delivery, Canada Institute for Scientific and Technical Information, Ottawa K1A 0S2, Canada (Tel: 613-993-9251; Fax: 613-952-8243; e-mail: cisti.docdel@nrc.ca).

\section{LINKAlert}

The LINKAlert service replaces the Springer Journals Preview Service. This journal is included in the LINKAlert service. LINKAlert is a free, subscribe-to feature of Springer-Verlag's LINK. After subscribing to LINKAlert, you will receive, via e-mail, tables of contents of new issues of your selected journals. The e-mail contains hyperlinks to the articles' abstracts and is sent when the issue is posted to LINK.

Subscribe to LINKAlert at http://link.springer-ny.com/alert.

\section{Subscription Information}

Microscopy and Microanalysis is published bimonthly in January, March, May, July, September, and November by Springer-Verlag, plus two supplements (Expo and Proceedings) to be published in May and June. Volume 4 will appear in 1998.

Society Rates: Members of the Microscopy Society of America should contact the MSA Business Office for all subscription inquiries.

Microscopy Society of America

435 North Michigan Avenue, Suite 1717

Chicago, IL 60611-4067

Toll-Free Tel: $800-538-3672$

Tel: $312-644-1527$

Fax: 312-644-8557

E-mail: businessoffice@msa.microscopy.com

Members of other affiliated societies should contact their respective society business offices for all subscription inquiries.

Institutional Rates: North America: US $\$ 539.00$ plus $\$ 18.00$ postage and handling. (Canadian customers please add 7\% GST to subscription price, then add postage and handling. Springer-Verlag's GST registration number is 123394918.) Subscriptions are entered with prepayment only. Please mail orders and inquiries to: Springer-Verlag New York, Inc. Journal Fulfillment Services Department, P.O. Box 2485, Secaucus, NJ 07096-2485, USA. Tel: 1-800-SPRINGER, Fax: (201) 348-4505. e-mail: journals@springer-ny.com.

Outside North America: Subscription rate: US $\$ 539.00$ (calculated in DM at the exchange rate current at time of purchase), plus postage and handling. SAL delivery (surface airmail lifted) is mandatory for Japan, India, Australia, and New Zealand. Customers should ask for the appropriate price list. Airmail delivery to all other countries is available upon request. Subscriptions can either be placed via a bookdealer or sent directly to: Springer-Verlag GmbH \& Co. KG, Postfach 3113 40, D-10643 Berlin, Germany. Tel: (030) 827 87-0, Fax: (030) 8214091.

Back volumes: Contact the Microscopy Society of America, 435 North Michigan Avenue, Suite 1717, Chicago, IL 60611-4067 (Tel: 800-5383672) for information.

Change of address: Allow six weeks for all changes to become effective. All communications should include both old and new addresses (with postal codes) and should be accompanied by a mailing label from a recent issue. Society members should contact their respective society business offices to inform them of address changes.

Microform editions are available from: University Microfilms International, 300 North Zeeb Road, Ann Arbor, MI 48106, USA.

\section{Editorial Office}

Dale E. Johnson, Editor in Chief, Graduate School, University of South Florida, 4202 E. Fowler Avenue, FAO 126, Tampa, FL 33620-7900, USA Tel: (813) 974-8118; Fax: (813) 974-5762; E-mail: dej@grad.usf.edu

\section{Office of Publication}

Springer-Verlag New York, Inc., 175 Fifth Avenue, New York, NY 10010, USA, Tel: (212) 460-1500; Fax: (212) 533-5977; Production Editor: Jacquelyn L. Goss

\section{Advertising Sales \& Production}

Brian Skepton, Advertising Sales Manager, Springer-Verlag New York, Inc., 175 Fifth Avenue, New York, NY 10010, USA, Tel: (212) 460-1700; Fax: (212) 533-0108

(C) 1998 by Microscopy Society of America. Printed in the United States on acid-free paper. Periodicals postage is pending at New York, NY and additional mailing offices. Postmaster: Send all address changes to $\mathrm{Mi}$ croscopy and Microanalysis, Journal Fulfillment Services Department, P.O. Box 2485, Secaucus, NJ 07096-2485. 
https://doi.org/10.1017/S1431927600020122 Published online by Cambridge University Press 


\section{PROCEEDINGS}

\section{MICROSCOPY AND MICROANALYSIS 1998}

Microscopy Society of America

56th Annual Meeting
Microbeam Analysis Society

32nd Annual Meeting

ATLANTA, GEORGIA

July 12-16, 1998

Edited by

G.W. Bailey

K.B. Alexander

W.G. Jerome

M.G. Bond

J.J. McCarthy

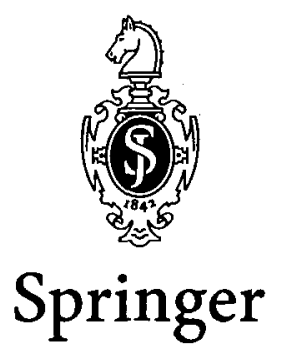

1998 


\section{MICROSCOPY SOCIETY OF AMERICA}

Established 1942

OFFICERS 1998

Executive Council

President

President Elect

Ralph M. Albrecht

Past President

David Joy

Secretary

Treasurer

C. Barry Carter

Ernest Hall

Directors

Ronald M. Anderson

Mary Grace Burke

Stanley L. Erlandsen

J. Murray Gibson

JoAn S. Hudson

José A. Mascorro

Avril Somlyo

David B. Williams

Appointed Officers

Archivist

Rachael A. Horowitz

Awards Committee Chair Mary Grace Burke

Certification Board Chair

Karen Klomparens

Committee on Standards Chair Eric B. Steel

Education Committee Chair Janet Woodward

International Committee Chair Robert P. Apkarian

Journal Editor-in-Chief Dale E. Johnson

Proceedings Editor G. William Bailey

Bulletin Editor Stuart McKernan

Long Range Planning Committee Chair John Silcox

Membership Committee Co-Chairs Ralph M. Albrecht Linda Horton

Placement Officer John H. L. Watson

Program Sponsorship Committee Chair Stanley L. Erlandsen

Public Policy Committee Chair Patricia G. Calarco Sustaining Members Committee Chair Paul E. Fischione

Technologists' Forum Beverly E. Maleeff

Telecommunications Committee Chair Nestor J. Zaluzec 1998 Local Arrangements Chair Janet Woodward 1998 Program Chair Kathleen B. Alexander 1998 Program Vice Chair Jay Jerome

$\begin{array}{cc}\text { Business Office } & \text { Bostrom Corporation } \\ \text { Meeting Manager } & \text { The Rebedeau Group }\end{array}$

vi 


\title{
MICROBEAM ANALYSIS SOCIETY
}

Established 1966

OFFICERS 1998

Executive Council

President

President Elect

Past President

Secretary

Treasurer

Directors

\author{
Ryna B. Marinenko \\ John J. Friel \\ Joseph R. Michael \\ Edgar S. Etz \\ Harvey A. Freeman \\ Paul Carpenter \\ Cathy Johnson \\ Richard W. Linton \\ Greg Meeker \\ Inga Holl Musselman \\ Donald L. Parker
}

Appointed Officers

Archivist, Finance Committee Chair Gordon Cleaver

Computer Activities Committee Chair John F. Mansfield

Corporate Liaison Committee Chair Thomas G. Huber

Education Committee Chair Phillip E. Russell

Historian Gordon Cleaver

International Liaison

David B. Williams

Long Range Planning Committee Chair John A. Small Membership Services Scott Wight

MicroNews Editor

Ryna A. Marinenko

Sustaining Members Committee Chair Cathy Johnson

MAS Business Office

William S. Thompson

vii 
4pi ANALYSIS, INC.

ADVANCED MICROBEAM, INC.

ADVANCED MICROSCOPY TECHNIQUES

ALLIED HIGH TECH PRODUCTS

AMERICAN NUCLEAR SYSTEMS, INC.

AMRAY, INC.

AMTEC

ANATECH LTD.

CARL ZEISS, INC.

CHARLES EVANS \& ASSOCIATES

CLEMEX TECHNOLOGIES, INC.

DEGROOT INDUSTRIES INTERNATIONAL, INC.

DELAWARE DIAMOND KNIVES, INC.

DENTON VACUUM, INC.

DIATOME U.S.

DIGITAL INSTRUMENTS, INC.

E. A. FISCHIONE INSTRUMENTS, INC.

EASTMAN KODAK CO.

EDAX INTERNATIONAL

EDGECRAFT CORP

EDGE SCIENTIFIC INSTRUMENT CORP. EDWARDS HIGH VACUUM INTERNATIONAL

EGOLTRONICS CORP.

ELECTRON MICROSCOPY SCIENCES

EMITECH U.S.A., INC.

ERNEST F. FULLAM, INC.

ETP-USA/ELECTRON DETECTORS

EVEX ANALYTICAL

FEI COMPANY

GATAN INC.

GW ELECTRONICS, INC.

HARRIS DIAMOND CORP.

HITACHI INSTRUMENTS, INC.

IBM ANALYTICAL SERVICES

JEOL-USA INC.

KAISER OPTICAL SYSTEMS, INC.

KEVEX

LADD RESEARCH INDUSTRIES

LAURIN PUBLISHING CO., INC.

LEO ELECTRON MICROSCOPY INC.

M. E. TAYLOR ENGINEERING, INC.

MAGER SCIENTIFIC INC.

MATERIALS ANALYTICAL SERVICES
MCCRONE RESEARCH INSTITUTE

MEDIA CYBERNETICS

MICRO STAR TECHNOLOGIES, INC.

MICRON, INC.

MICROSCOPE BOOK

MICROSCOPY, MARKETING \& EDUCATION

MICROSCOPY TODAY

MPK TECHNOLOGY, INC.

NSA/HITACHI SCIENTIFIC INSTRUMENTS

NAT'L. METAL \& MATERIALS TECHNOLOGY

CENTER

NIKON INC.

NORAN INSTRUMENTS

OMEGA OPTICAL INC.

OPTRONICS ENGINEERING

OSMIC INC.

OXFORD INSTRUMENTS

PARK SCIENTIFIC INSTRUMENTS

PHILIPS ELECTRON OPTICS

PLENUM PUBLISHING

POLAROID CORP.

POLYSCIENCES, INC.

PRINCETON GAMMA-TECH, INC.

PRINCETON INSTRUMENTS, INC.

RAITH USA, INC.

RJ LEE GROUP, INC.

SAMx

SCANALYTICS

SCIENTIFIC INSTRUMENTATION SERVICES, INC.

SEMICAPS, INC.

SOUTH BAY TECHNOLOGY, INC.

SPECTRA-TECH, INC.

SPI SUPPLIES

TECHNOTRADE INTERNATIONAL

TED PELLA, INC.

TOPCON TECHNOLOGIES, INC.

TOPOMETRIX

TOUISIMIS

UNIVERSAL IMAGING CORP.

VBS INDUSTRIES

VIRTUAL LABORATORIES

VITAL IMAGE TECHNOLOGY

XEI SCIENTIFIC 
4pi ANALYSIS INC.

ADVANCED MICROBEAM INC.

AMRAY INC.

CAMECA INSTRUMENTS INC.

CHARLES EVANS \& ASSOCIATES

DENTON VACUUM INC.

EDAX INTERNATIONAL

ELECTRON MICROSCOPY SCIENCES/DIATOME US

ETP-USA/ELECTRON DETECTORS INC.

FEI COMPONENTS GROUP

GATAN, INC.

GELLER MICROANALYTICAL LABORATORY

HESSLER TECHNICAL SERVICES

IBM ANALYTICAL SERVICES

JEOL-USA INC.

KEVEX INSTRUMENTS

LEHIGH UNIVERSITY
MATERIALS ANALYTICAL SERVICES, INC. MICRON, INC.

NISSEI SANGYO AMERICA, LTD. HITACHI SCIENTIFIC INSTRUMENTS NORAN INSTRUMENTS, INC. OSMIC, INC.

OXFORD INSTRUMENTS, INC. MICROANALYSIS GROUP

PARK SCIENTIFIC INSTRUMENTS

PHILIPS ELECTRON OPTICS

PHYSICAL ELECTRONICS, INC.

PRINCETON GAMMA-TECH INC.

RJ LEE INSTRUMENTS, LTD.

SEM/TEC LABORATORIES

SPECTRA-TECH/NICOLET

TOPCON TECHNOLOGIES, INC. 


\section{MICROSCOPY SOCIETY OF AMERICA}

\section{DISTINGUISHED SCIENTIST AWARDS}

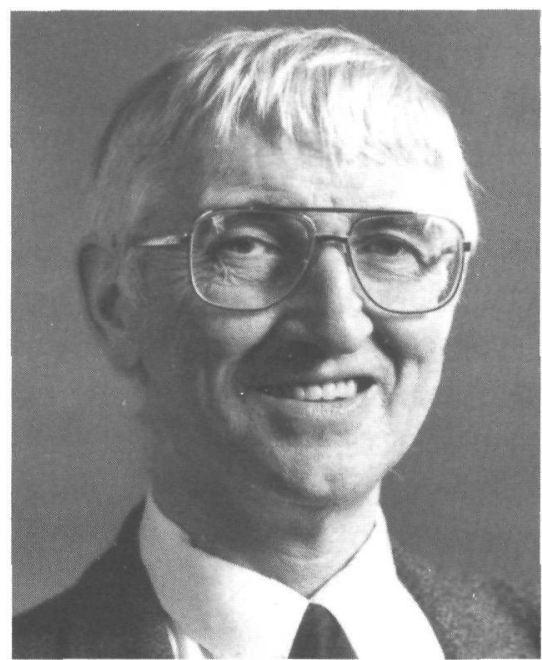

MICHAEL J. WHELAN

Physical Sciences

He graduated in physics from the University of Cambridge in 1954, and started research there in the Cavendish Laboratory of the Department of Physics. Working with Dr. Peter Hirsch, he followed up a line of research which had been recently initiated by A Kelly, PB Hirsch and JW Menter to try to observe directly crystal lattice defects in thin foils of metals by transmission electron microscopy. He first investigated ion beam thinning of gold, aluminium and other metals using laboratory constructed equipment, since no commercial equipment was then available. Success was achieved in the spring of 1956, when dislocations were observed in thin foils of aluminium, and their motion captured on movie film. Later that year, in collaboration with $W$ Bollmann of the Battelle Labs in Geneva, the movement of dislocations was observed in stainless steel, a metal of low stacking fault energy, and the splitting of the dislocations in to partials with an associated stacking fault was studied. The TEM technique is now widely used for characterising defects in materials. In 1958 he received his Ph.D., and after further research in Cambridge he moved in 1966 to the Department of Metallurgy of the University of Oxford, where he held the post of Reader and later of Professor. He retired from his Professorship in 1997.

During his career he pioneered with his collaborators many techniques in the field of materials applications of electron microscopy. These include theories of image contrast, studies at elevated temperatures using a heating specimen stage, the weakbeam technique for high resolution observations of dislocations by diffraction contrast, electron energy loss spectroscopy, and in recent years the theory of reflection high energy electron diffraction with applications to molecular beam epitaxy.

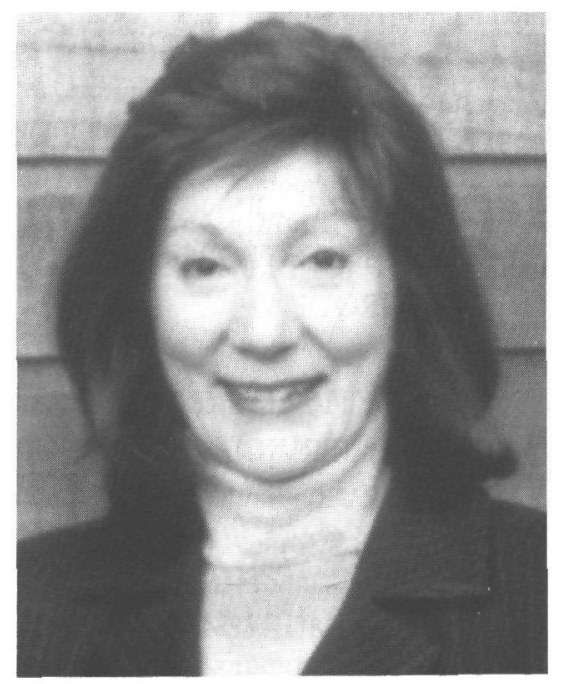

\section{AVRIL V. SOMLYO \\ Biological Sciences}

Avril V. Somlyo has contributed to the development and application of analytical $\mathrm{X}$-ray microprobe microanalysis to biological specimens, as well as rapid freezing technologies, to trap physiological events in cells and tissues. This approach has led to new insights into the transport of elements across the membranes of intracellular organelles, such as mitochondria, sarcoplasmic and endoplasmic reticulum and the nucleus in situ. Dr. Somlyo and her colleagues are currently studying signal transduction pathways, which regulate smooth muscle contractility, as well as the myosin molecular motors responsible for force generation. Dr. Somlyo received her Ph.D. in 1976 from the University of Pennsylvania and is currently Professor of Pathology and Molecular Physiology and Biological Physics at the University of Virginia School of Medicine. Dr. Somlyo has received the CIBA Award for Hypertension Research, the Louis and Artur Lucian Award for Research in Circulatory Diseases, and the Presidential Science Award of the Microbeam Analysis Society. 


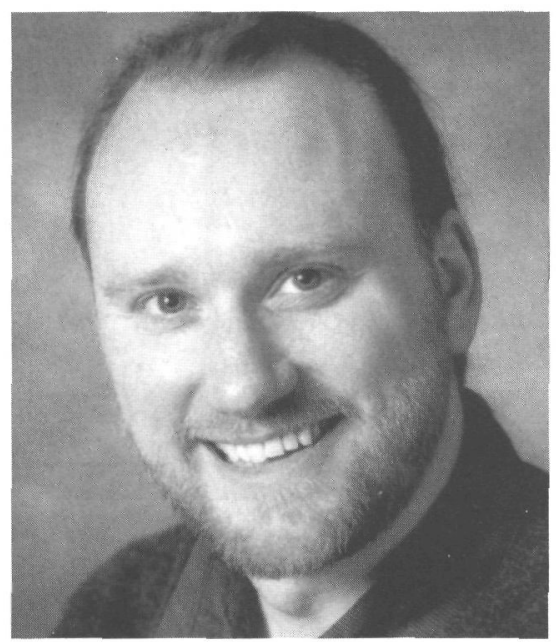

IAN M. ANDERSON

Ian M. Anderson received a B.S. degree from Caltech and M.Eng., M.S., and Ph.D. degrees from Cornell, all in Applied Physics. He received an (E)MSA Presidential Scholarship to attend the 50th anniversary meeting in 1992 while he was finishing his dissertation at the University of Minnesota. Since 1993, he has been at Oak Ridge National Laboratory, where he is currently a research staff member in the Metals and Ceramics Division. Dr. Anderson's research is in the development of electron-optical characterization techniques and their applications for materials analysis. His research has included the areas of secondary fluorescence corrections, ALCHEMI, energy-filtered imaging, low-voltage $\mathrm{X}$-microanalysis, and the development of methods for analysis of large series of spectra and images, for which he organized a symposium at Microscopy and Microanalysis '97. He has been a member of the Program Committee since 1996. 
THE MORTON D MASER

MSA DISTINGUISHED SERVICE AWARD

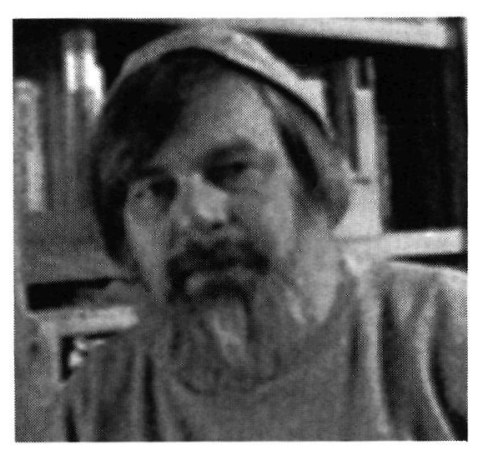

NESTOR J. ZALUZEC

Nestor is presently a research scientist at Argonne National Laboratory and has worked in the area of microstructural characterization using electron/optical techniques for over 20 years. He received a B.S. in Physics from the Illinois Institute of Technology and a $\mathrm{PhD}$ in Metallurgy from the University of Illinois Urbana/Champaign. He was a Wigner Fellow at ORNL and has received awards from International Microscopy Societies for his contributions in the field of Microscopy and Microanalysis. A member of MSA since 1979, he was awarded the Societies Burton Medal in 1982. He is a member of the Education, Standards, Program, and the Telecommunications Committees. Nestor also holds Adjunct Professorial Appointments in Physics at UIC and in Materials Science at UIUC. He has developed some of the original methodologies for quantitative elemental characterization using XEDS, EELS, and EFI in the $\mathrm{AEM}$ and continues to work on new technologies and instrumentation for characterization. His most recent research centers on the ANL $300 \mathrm{kV}$ AAEM and TelePresence Microscopy. He can sometimes be found on the Net and has known to handle a few Email and WWW requests for the Society. 




BIOLOGICAL SCIENCE

H.H. MOLLENHAUER

Dr. Mollenhauer received his degrees in electrical engineering from The University of Texas in Austin. His early work in electron microscopy was at the Cell Research Institute, The University of Texas, Austin. In 1965, he moved to the Charles F. Kettering Research Laboratory in Yellow Springs, Ohio and from there to the USDA, Veterinary Toxicology Research Laboratory, College Station, Texas. He retired in early 1992. Some of his early achievements included verifying the role of Golgi apparatus in plant secretion and cell wall formation, discovery of intercisternal elements and cis to trans polarity of plant dictyosomes, isolation of Golgi apparatus from plants and animals, and the first report of a new organelle (together with William Zebrun) called dictyosome-like structure (DLS). The DLS are unique to early spermatocytes where they coexist with Golgi apparatus. He has also published numerous papers for improving fixation, embedding, and sectioning of biological material.

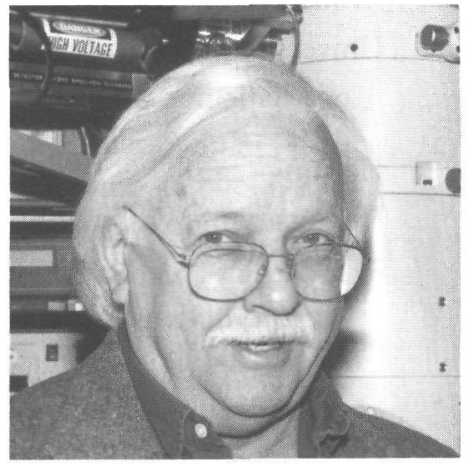

\section{PHYSICAL SCIENCE \\ C.J. ECHER}

Chuck Echer started materials characterization in 1960 during his formal education at Oklahoma State University where he graduated with two Associate Degrees in 1963. His initial career started at ACF Industries, Albuquerque, NM performing thermal-mechanical processing treatments of metals along with optical metallography evaluations. He continued his experience at Battelle Memorial Institute, Columbus, $\mathrm{OH}$ in the mid-sixties performing optical metallography on space age materials. In 1968, he joined Lawrence Livermore National Laboratory where he started materials characterization using transmission electron microscopes. In 1984, he transferred to the E.O. Lawrence Berkeley Laboratory, National Center for Electron Microscopy. His senior position currently provides user scheduling, training and collaborative research managing the AEM and the In-Situ facilities. In his career he has contributed to the installation of four electron microscope facilities. To date, he has co-authored sixty publications, received twelve awards, and chaired or co-chaired in eleven scientific meetings. 

A.-M. Broome
D.M. Longo
University of South Carolina School
University of Virginia
of Medicine
D.Y. Takamoto
H. Fong
University of Washington
University of California-
G.J. Jensen
Santa Barbara
Stanford University
T.S. Wakefield
Auburn University
M.T. Johnson
Y. Wang
University of Washington
Michigan Technological University
L.B. Kong
$X$. Yan
UCLA School of Medicine
Purdue University

1998 MSA PROFESSIONAL TECHNICAL STAFF AWARDS

Elizabeth R. Fischer

NIH-Rocky Mountain Laboratories

Rachel Horowitz

University of Massachusetts Medical School

Victoria J. Madden

University of North Carolina at Chapel Hill 
Biological Sciences

1975

1976

1977

1978

1979

1980

1981

1982

1983

1984

1985

1986

1987

1988

1989

1990

1991

1992

1993

1994

1995

1996

1997

1975

1976

1977

1978

1979

1980

1981

1982

1983

1984

1985

1986

1987

1988

1989

1990

1991

1992

1993

1994

1995

1996

1997
Keith Porter

L.L. Marton

Robley Williams

Thomas Anderson

Daniel Pease

George Palade

Sanford Palay

Richard Eakin

Hans Ris

Cecil Hall

Gaston Dupouy

F.O. Schmitt

Marilyn Farquhar

Morris Karnovsky

Don W. Fawcett

Audrey M. Glauert

Hugh E. Huxley

Fritiof Sjöstrand

Jean-Paul Revel

Andrew Somlyo

Shinya Inoué

Myron C. Ledbetter

S. J. Singer

\section{MSA BURTON MEDALIST}

James Lake

Michael Isaacson

Robert Sinclair

David Joy

Norton B. Gilula

John Spence

Barbara Panessa-Warren

Nestor Zaluzec

Ronald Gronsky

David B. Williams

Richard Leapman

J. Murray Gibson

Ronald Milligan

A.D. Romig, Jr.

Laurence D. Marks

W. Mason Skiff

Joseph R. Michael

Kannan Krishnan

Joseph A. N. Zasadzinski

Jan M. Chabala

Joanna L. Batstone

Vinayak P. Dravid

P. M. Ajayan

Physical Sciences

1975

1976

1977

1978

1979

1980

1981

1982

1983

1984

1985

1986

1987

1988

1989

1990

1991

1992

1993

1994

1995

1996

1997

\section{MSA DISTINGUISHED SERVICE AWARD}

1992

1993

1994

1995

1996

1997

\section{MSA OUTSTANDING TECHNOLOGIST AWARD}

1993 Ben O. Spurlock

1994 Bernard J. Kestel

1995

1996

1997
Robert Heidenreich

Albert Crewe

ames Hillier

E. Cosslet

Vladimir Zworykin

Benjamin M. Siegel

Peter Hirsch

Jan LePoole

Hatsujiro Hashimoto

mar Zeitler

Gertrude F. Rempfer

Archie Howie

Oliver Wells

hilcox

Ronald Anderson

G.W. "Bill" Bailey

Frances Ball

Blair Bowers

Deborah Clayton

Joseph Harb

Kenneth Lawless

Morton Maser

Caroline Schooley

John H.L. Watson

E. Laurence Thurston

Richard F.E. Crang

Raymond K. Hart

José A. Mascorro

William T. Gunning, III

Kai Chien

David W. Ackland

John P. Benedict

Stanley J. Klepeis 


$\begin{array}{ll}1942 & \text { G.L. Clark } \\ 1943 & \text { R. Bowling Barnes } \\ 1944 & \text { R. Bowling Barnes } \\ 1945 & \text { James Hillier } \\ 1946 & \text { David Harker } \\ 1947 & \text { William G. Kinsinger } \\ 1948 & \text { Perry C. Smith } \\ 1949 & \text { F.O. Schmitt } \\ 1950 & \text { Ralph W.G. Wyckoff } \\ 1951 & \text { Robley C. Williams } \\ 1952 & \text { R.D. Heidenreich } \\ 1953 & \text { Cecil E. Hall } \\ 1954 & \text { Robert G. Picard } \\ 1955 & \text { Thomas F. Anderson } \\ 1956 & \text { William L. Grube } \\ 1957 & \text { John H.L. Watson } \\ 1958 & \text { Max Swerdlow } \\ 1959 & \text { John H. Reisner } \\ 1960 & \text { D. Gordon Sharp } \\ 1961 & \text { D. Maxwell Teague } \\ 1962 & \text { Keith R. Porter } \\ 1963 & \text { Charles Schwartz } \\ 1964 & \text { Sidney S. Breese } \\ 1965 & \text { Virgil G. Peck } \\ 1966 & \text { Walter Frajola } \\ 1967 & \text { Joseph J. Comer } \\ 1968 & \text { John H. Luft } \\ 1969 & \text { W.C. Bigelow }\end{array}$

${ }^{1}$ Chair of committee to arrange first meeting ${ }^{2}$ Temporary (pre-constitution)

\begin{tabular}{ll}
1970 & Russell Steere \\
1971 & Robert M. Fisher \\
1972 & Daniel C. Pease \\
1973 & Benjamin Siegel \\
1974 & Russell J. Barnett \\
1975 & Gareth Thomas \\
1976 & Etienne de Harven \\
1977 & T.E. Everhart \\
1978 & Myron Ledbetter \\
1979 & John Silcox \\
1980 & Michael Beer \\
1981 & John Hren \\
1982 & Lee Peachey \\
1983 & David Wittry \\
1984 & J. David Robertson \\
1985 & Dale Johnson \\
1986 & Robert Glaeser \\
1987 & Linn W. Hobbs \\
1988 & John-Paul Revel \\
1989 & Ray Carpenter \\
1990 & Keith R. Porter \\
1991 & Charles Lyman \\
1992 & Patricia Calarco \\
1993 & Michael S. Isaacson \\
1994 & Robert R. Cardell \\
1995 & Terence E. Mitchell \\
1996 & Margaret Ann Goldstein \\
1997 & C. Barry Carter \\
\hline &
\end{tabular}

1970 Russell Steere

1972 Daniel C. Pease

1973 Benjamin Siegel

1974 Russell J. Barnett

1977 T.E. Everhart

1978 Myron Ledbetter

1981 John Hren

1982 Lee Peachey

1984 J. David Robertson

1985 Dale Johnson

1986 Robert Glaeser

W. Hobbs

John-Paul Reve

1989 Ray Carpenter

$1990 \quad$ Keith R. Porter 


\section{MICROBEAM ANALYSIS SOCIETY AWARDS PRESIDENTIAL SCIENCE AWARD}



FREDERICK H. SCHAMBER

Frederick H. Schamber received his Ph.D. in physics at Iowa State University in 1970 . He joined Tracor Northern in 1972 where he developed x-ray analyzer software and managed the research and development activities. He joined RJ Lee Group in 1990 and is currently Vice President of RJ Lee Instruments Limited with responsibility for product development and corporate direction. Fred's professional interests have focused on instrumentation development, with spectral analysis, computer automation, and electron optics design being particular emphases. His 1973 invention and publication of the filtered least-squares fit from reference spectra provided the emerging EDS industry with its first on-line method for reliable quantification of complex EDS spectra. He has been, and continues to be, extensively involved in the development of automated and integrated SEM/EDS instrumentation. Fred has served as a director of MAS and was the 1978 recipient of the society's Corning award for best contributed paper. 


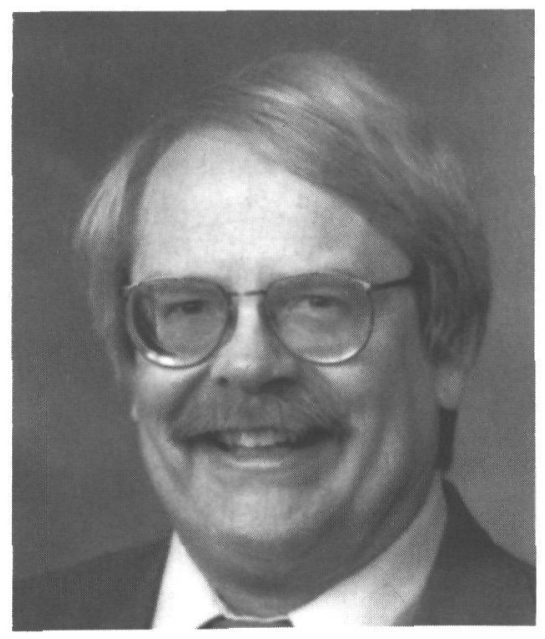

JON J. MCCARTHY

Jon is a native of Wisconsin and received a BS in physics and mathematics from the University of Wisconsin-Eau Claire. He received the Ph.D. in Physics from Iowa State University, following in the footsteps of such other famous MAS members as Bob Myklebust, Joe Doyle, and Fred Schamber! After a two year post-Doc appointment in the Center for Radiation Research at NIST (formerly NBS), Jon joined NORAN Instruments (formerly Tracor Northern) as a senior scientist where he is now Vice-President of Technology and Engineering. Jon has been a member of MAS since 1976 and has served the society in many roles. He has been a MAS tour speaker on three occasions, and was a session chair at the 92,94 and 97 meetings. In 1997 he was the MAS program chair for the M\&M meeting, and this year he is the MAS co-chair for M\&M ' 98 while also organizing the MAS Topical Symposium celebrating Thirty Years of EDS in Microanalysis. In addition, Jon has served on the MAS council as a director (1989-91), as a corporate liaison (1992-3), and as MAS president (1995).

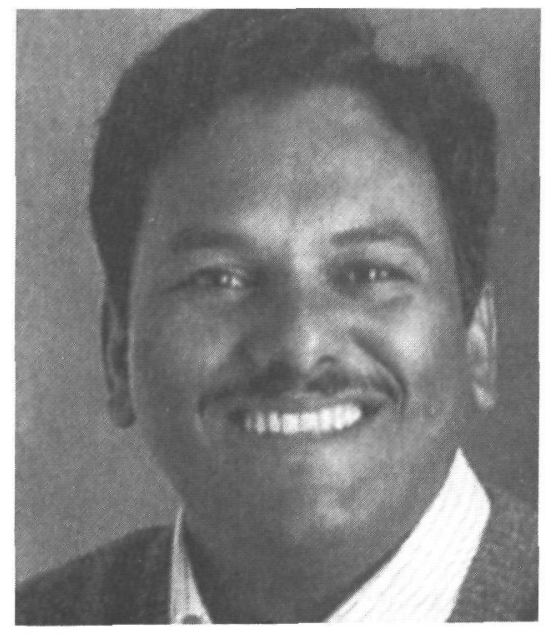

VINAYAK P. DRAVID

Vinayak P. Dravid received his undergraduate B.Tech degree in Metallurgical Engineering from the Indian Institute of Technology (IIT), Bombay-India in 1984, and his PhD in Materials Science \& Engineering in fall of 1990 from Lehigh University. He then gathered his courage to venture into academic career the same year with the Department of Materials Science \& Engineering at Northwestern University. $\mathrm{He}$ is now an associate professor and directs the electron probe instrumentation center (EPIC).

Professor Dravid's research and teaching interests revolve around nanoscale phenomena in solids-specifically interfacial phenomena in ceramics and nanostructured materials, and the prudent use of emerging as well as conventional electron microscopy techniques. He has authored over 80 refereed journal publications and holds several patents in these areas. Prof. Dravid is a recipient of various research awards including: NSF Young Investigator Award, Exxon Foundation Fellowship, IBM Faculty Development Award, the Microscopy Society of America (MSA) Burton Medal and the Robert L. Coble award from the American Ceramic Society. He has been affiliated with the MAS since his graduate days, and has served the microscopy and microanalysis community in various capacities. One of Prof. Dravid's passions (and challenges) is to increase societal awareness of science and technology, specifically that in materials science and technology. He enjoys touring and hosting local area high schools, and attempts to convey the beauty, diversity and complexity of materials via electron microscopy and microanalysis. 
Z.W. Chen

University of Southern California

K.D. Johnson

Northwestern University

R.J. Kline

North Carolina State University

P.M. Raj

Rutgers University
K. Siangchaew

Stevens Institute of Technology

A.P. Smith

North Carolina State University

W. Tian

University of Michigan

S.H. Wood

University of California-Riverside

MAS PRESIDENTIAL AWARDS

Science

Service

1977

R. Castaing

1977

P. Lublin

1978

K.F.J. Heinrich

1978

D.R. Beaman

1979

P. Duncumb

1979

M.A. Giles

1980

D.B. Wittry

1980

A.A. Chodos

1981

S.J. Reed

1982

R. Shimizu

1981

R. Myklebust

1983

J. Philibert

1982

J. Doyle

1984

L.S. Birks

1985

E. Lifshin

1986

R. Myklebust

1983

D. Newbury

1984

J.I. Goldstein

1985

M.C. Finn

1987

O.C. Wells

1986

V. Shull

1988

J.D. Brown

1987

D.C. Joy

1989

J. Hillier

1990 T.E. Everhart

1988

C.G. Cleaver

1991

J.I. Goldstein

1989

W.F. Chambers

1992

G. Lorimer

1990

C.E. Fiori

1991

1992

T.G. Huber

G. Cliff

1993

E. Etz

1993

D.E. Newbury

1994

H.A. Freeman

1994

D.C. Joy

J.L. Worrall

1995

G. Bastin

1995

1996

R.W. Linton

1996

A.V. Somlyo

1997

P.F. Hlava
A.P. Somlyo

1997

D.B. Williams

MAS K.F.J. HEINRICH AWARDS

$\begin{array}{llll}1986 & \text { P. Statham } & 1991 & \text { A.D. Romig, Jr. } \\ 1987 & \text { J.T. Armstrong } & 1992 & \text { S. Pennycook } \\ 1988 & \text { D.B. Williams } & 1993 & \text { P.E. Russell } \\ 1989 & \text { R. Leapman } & 1994 & \text { J.R. Michael } \\ 1990 & \text { R.W. Linton } & 1995 & \text { N. Lewis } \\ & & 1997 & \text { R. Gauvin }\end{array}$

xix 
MAS PAST PRESIDENTS

$\begin{array}{llll}1968 & \text { L.S. Birks } & 1983 & \text { R. Bolon } \\ 1969 & \text { K.F.J. Heinrich } & 1984 & \text { D.C. Joy } \\ 1970 & \text { R.E. Ogilvie } & 1985 & \text { D.E. Newbury } \\ 1971 & \text { A.A. Chodos } & 1986 & \text { C.G. Cleaver } \\ 1972 & \text { K. Keil } & 1987 & \text { C. Fiori } \\ 1973 & \text { D.R. Beaman } & 1988 & \text { W.F. Chambers } \\ 1974 & \text { P. Lublin } & 1989 & \text { D.B. Wittry } \\ 1975 & \text { J.W. Colby } & 1990 & \text { A.D. Romig, Jr. } \\ 1976 & \text { E. Lifshin } & 1991 & \text { J.T. Armstrong } \\ 1977 & \text { J.I. Goldstein } & 1992 & \text { D.B. Williams } \\ 1978 & \text { J.D. Brown } & 1993 & \text { T.G. Huber } \\ 1979 & \text { D.F. Kyser } & 1994 & \text { J. Small } \\ 1980 & \text { O.C. Wells } & 1995 & \text { J. McCarthy } \\ 1981 & \text { J.R. Coleman } & 1996 & \text { D.E. Johnson } \\ 1982 & \text { R. Myklebust } & 1997 & \text { Joseph R. Michael }\end{array}$


MICROSCOPY AND MICROANALYSIS 1998

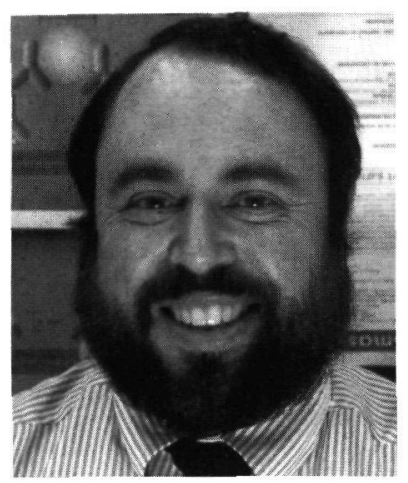

Ralph M. Albrecht MSA President

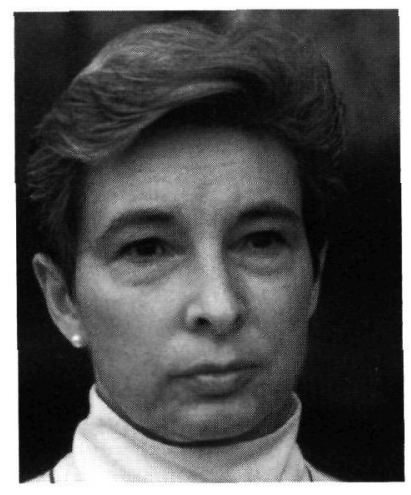

Ryna B. Marinenko MAS President 


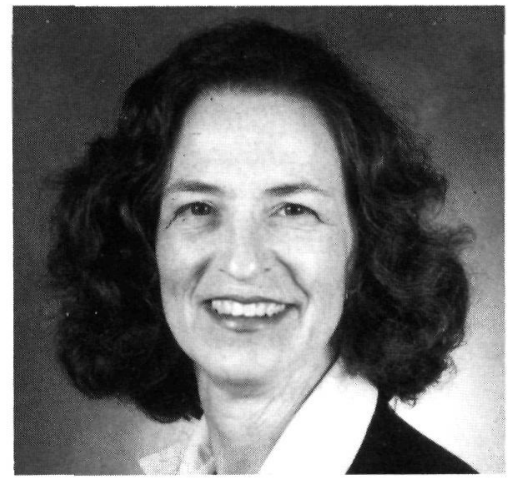

Janet Woodward

Local Arrangements Chair

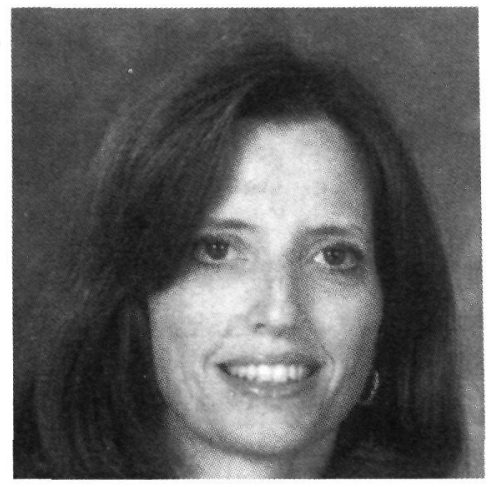

Kathleen B. Alexander

Program Chair

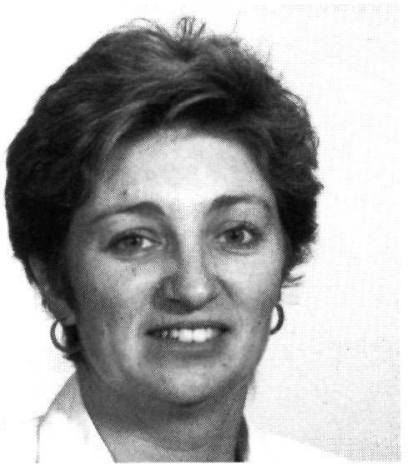

Meredith Bond

Program Co Chair

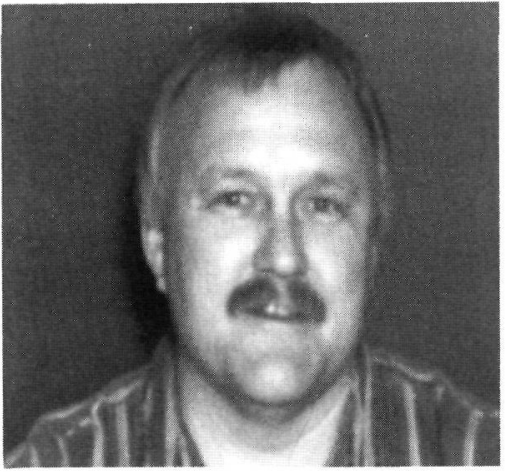

Robert L. Price

Local Arrangements Treasurer



Jay Jerome

Program Vice Chair



Jon J. McCarthy Program Co Chair 


\section{PROGRAM COMMITTEE}

Kathleen B. Alexander, Chair Jay Jerome, Vice Chair Meredith Bond, Co Chair Jon J. McCarthy, Co Chair

Danny Akin

Ralph Albrecht

Ian Anderson

Ron Anderson

John Armstrong

John Basgen

Jim Bentley

Mary Buckett

Mary Grace Burke

Peter Crozier

Ken Downing

Mark Ellismanı

Stan Erlandson

Raynald Gauvin

Steve Goodman

Bill Gunning

Jim Hainfeld

Eric Henderson

Brian Herman

Fred E. Hossler

Robert Hull

Charles Humphrey

Peter Ingram

David Joy

Louis Kerr

Mike Kersker

Matt Libera

Beverly Maleeff

John Mansfield

Ryna Marinenko
José Mascorro

Joerg Maser

Frederick R. Maxfield

Stuart McKernan

Doug Medlin

Greg Meeker

Mike Miller

Sara Miller

Jeremy Mitchell

Terry Mitchell

David Muller

Dale Newbury

Mike O'Keefe

Jim Pawley

Steve Pennycook

Bob Price

John A. Reffner

Klaus-Ruediger Peters

Phil Russell

Fred Schamber

Sandy Silvers

Gina Sosinsky

Alasdair Steven

Jim Turner

Edgar Voelkl

Z.L. Wang

Mark Willingham

Janet Woodward

Nestor Zaluzec

Yimei Zhu 


\title{
FOREWORD
}

\author{
Ralph Albrecht \& Ryna Marinenko \\ President MSA and President MAS
}

Beginning with last year's volume, the proceedings of the annual meeting are being published as a supplement to our Journal, "Microscopy and Microanalysis". It should also be noted that "Microscopy and Microanalysis" is now abstracted by Current Contents in both the biological and physical science categories. The Journal is also abstracted by Biosis and by Chemical Abstracts. Hence the scientific content of Microscopy and Microanalysis can now be readily searched and is widely available. Both the meeting and the proceedings continue as a joint MSA/MAS effort under the direction of a single Program Committee, a single Local Arrangements Committee, and are published as a single Proceedings. We have also continued the Presidential Happenings "tradition" begun last year where our awards ceremonies are coupled with presentations that all meeting participants will find interesting and enjoyable.

We wish to congratulate the Program Committee chaired by Kathi Alexander and the Local Arrangements Committee chaired by Janet Woodward for their hard work and dedication in making Microscopy and Microanalysis '98 an outstanding meeting. Despite this year's earlier-than-usual meeting date and hence an earlier abstract due date, all indications are that this is one of the most successful MSA/MAS sponsored meetings both in terms of participation and attendance. Kathi and co-chairs Jay Jerome (MSA), Meredith Bond (MAS), and Jon McCarthy (MAS) have worked extremely hard during the past two years arranging sessions, speakers, pre-meeting workshops, tutorials, etc. The result is a comprehensive program of platform and poster symposia complimented by a variety of special offerings including a special pre-meeting symposium/workshop on multiphoton excitation microscopy presented by Jim Pawley, an excellent program of pre-meeting short courses organized by Brian Herman and Louis Kerr, and a special MAS symposium entitled "30 Years of Energy Dispersive Spectrometry". James Turner and John Mansfield have put together an outstanding set of tutorials, the computer workshop will be presented by Nestor Zaluzec and John Mansfield, while Sandy Silvers and Bev Maleeff from The Technologist's Forum have arranged a special discussion on image manipulation and enhancement as well as a symposium on the selection and use of instrumentation. The LAC under Janet Woodward's leadership has been equally instrumental to the success of the meeting in arranging for our world class meeting site, exciting social events, hotels, shuttles, etc. This year marks the first Microscopy and Microanalysis Meeting managed by the Rebedeau Group (headed by Mary Beth Rebedeau) which has been working closely with both the LAC and the Program Committee developing an advanced and streamlined program production process as well as coordinating on site meeting management.

Our thanks to Bill Bailey, the MSA Proceedings Editor, who, over the years, has been instrumental in producing these first class Proceedings and who sent us many friendly reminders to insure the timely submission of contributions needed for the Proceedings. We appreciate his tireless dedication. We also wish to express our appreciation to the extremely competent and professional staff at Springer Verlag for their attentive efforts in publishing our journal and, in particular, this Proceedings issue.

We also extend our hearty congratulations to the MSA and MAS award winners. Avril Somlyo and Mike Whelan have been selected as recipients for the MSA Distinguished Scientist Awards in the Biological and Physical Sciences respectively. Ian Anderson is the MSA Burton Medalist and Nestor Zaluzec is the recipient of the MSA Morton D Maser Outstanding Service Award. The MSA Outstanding Technologist Awards go to Charles Echer in the Physical Sciences category and to Hilton Mollenhauer in the Biological Sciences category. The recipient of the MAS Presidential Science Award is Fred Schamber, the MAS Presidential Service Award goes to Jon McCarthy, and the K.F.J. Heinrich Award recipient is Vinayak Dravid. Congratulations also to the 10 MSA Presidential Student Awardees, the 3 recipients of MSA Professional Technical Staff Awards, and the 8 MAS Distinguished Scholar Awardees.

xxiv 
Atlanta is a hub for science, communication, and travel. It is a vibrant city with great natural beauty, many modern and historical sites of interest, outstanding restaurants and shops, and an efficient, inexpensive public transportation system. Our special thanks to the City of Atlanta for the hospitality they have extended to us. We are pleased to have been able to select The Georgia World Congress Center, an outstanding internationally recognized facility, as the venue for our scientific sessions and exhibits. We thank all the organizers and participants for making Microscopy and Microanalysis 1998 a premier event. We now look forward to Portland, Oregon, the site of Microscopy and Microanalysis '99. 
https://doi.org/10.1017/S1431927600020122 Published online by Cambridge University Press 


\section{ADVANCES IN REMOTE MICROSCOPY, INSTRUMENT AUTOMATION AND DATA STORAGE}

Possibilities and examples for remote microscopy including digital image acquisition, transfer, and archiving-I. Daberkow, M. Schierjott

Quicktime as a storage medium for dynamic data sets in in-situ electromicroscopy-J. F. Mansfield

The Materials Microcharacterization Collaboratory-M. C. Wright

A testbed for automated acquisition from a TEM-C. S. Potter, B. Carragher, H. Chu, B. J. Frey, R. Josephs,

C. Lin, N. Kisseberth, K. L. Miller, K. Nahrstedt

A model for Internet access to remote visual scientific instruments-C L. Morgan, R. A. Hillyard, G. M. Jones,

D. L. Pardoe, N. R. Smith

Telemicroscopy: Development of a Collaboratory for Microscopic Digital Anatomy-M. H. Ellisman, M. Hadida,

D. Greer, M. Wong, S. Lindsey, S. Peltier, S. J. Young

Network control and tools for electron microscopy-J. A. Hunt, C. Meyer

SEM stop-frame, color, 3D animation for motion pictures-D. Scharf, J. Wilbrink, J. A. Hunt

Tele-Presence Microscopy: A progress report-N. J. Zaluzec

A telepresence microscopy research session in the DOE2000 materials microcharacterization collaboratory

-L. F. Allard, E. Voelkl, T. A. Nolan, C. K. Narula, C. Montreuil, W. C. Bigelow, J. F. Mansfield

National Institute of Standards and Technology-Texas Instruments industrial collaboratory testbed-

M. T. Postek, M. Bennett, N. J. Zaluzec, T. Wheatley, S. Jones ..................................................................... 22

A generic protocol for controlling an SEM over a TCP/IP link-N. W. M. Ritchie, P. V. Woods ......................... 24

Tele-tutoring-from learning to earning-West Greene School District Team, RJ Lee Group Team,

L. S. Koshinski, L. T. Weinrich

TEM performance evaluations with slow-scan CCD cameras-M. Pan

A multi-instrument virtual collaborative environment via the World Wide Web at NIST-B. B. Thorne,

E. B. Steel, A. J. Fahey

Televisualization: An aid to collaborative research in molecular structure biology-M. F. Schmid, P. Matsudaira,

M. T. Dougherty, M. B. Sherman, C. Henn, W. Chiu

Design and implementation of a laboratory-wide image management system based on Microsoft Windows

NT and optical storage technology-R. McGill

Centrifuge polarizing microscope-S. Inoué, R. A. Knudson, K. Suzuki, N. Okada, H. Takahashi, M. Iida,

K. Yamanaka

Virtual EDS-A cross-platform interactive multimedia tool for self-paced instruction in energy dispersive

spectroscopy and microanalysis-B. J. Griffin, C. E. Nockolds

A model outreach program for teaching scanning electron microscopy technology: Successes and failures-

N. R. Smith, R. A. Quinta

LBNL and the Materials Microcharacterization Collaboratory-M. A. O'Keefe, J. R. Taylor, D. K. Owen

Real-time remote control of a scanning electron microscope across the vBNS/Internet 2-J. F. Mansfield,

A. Adamson, K. Coffman 
Interactive nanovisualization for science and engineering education-Scanning probe microscope on the Web-B. L. Ramakrishna, A. Razdan, J. Sun, E. Ong, A. A. Garcia

Integrated data acquisition and instrument control for local and remote operation of electron microscopes equipped with imaging detectors and spectrometers-W. J. de Ruijter, J. K. Weiss

Towards sub-Ångstrom resolution with a $200 \mathrm{kV}$ TEM by means of a Cs-corrector and a computer controlled alignment procedure-M. Haider, S. Uhlemann

\section{APPLIED IMAGE PROCESSING: WHAT IT CAN DO FOR DIGITAL IMAGING}

Acquisition and processing of large dynamic range digital images-J. A. Hunt

Understanding digital color imaging and processing-B. D. Newell

Edge sharpening for unbiased edge detection in field emission scanning electron microscope (FESEM)

Images-P. M. Raj, S. M. Dunn, W. R. Cannon

Extracting objects with adaptive segmentation techniques: Going beyond intensity thresholding-P. Eggleston ...

Montages and virtual reality-A paradigm for presentation of analytical data-S. K. Kennedy, D. Barton,

H. P. Lentz, J. Newlin, P. M. Sauter, F. C. Schwerer

Digital image acquisition and presentation for high resolution SEM-Y. Chen

Digital precision imaging: Every pixel counts-K.-R. Peters

IMAGING AND ANALYSIS AT THE ATOMIC LEVEL: 30 YEARS OF ATOM PROBE FIELD ION MICROSCOPY

Anecdotes from an atom-probe original-J. A. Panitz

The position-sensitive atom probe-A new dimension in atom probe analysis-A Cerezo, P. J. Warren,

G. D. W. Smith

The tomographic atom probe: A new dimension in material analysis-B. Deconihout, P. Pareige, D. Blavette,

A. Bostel, A. Menand

A transparent anode array detector for 3D atom probes-M. K. Miller

Development of the scanning atom probe and atomic level analysis-O. Nishikawa, T. Sekine, Y. Ohtani,

K. Maeda, Y. Numada, M. Watanabe, M. Iwatsuki, S. Aoki, J. Itoh, K. Yamanaka

Towards 3D lattice reconstruction with the position sensitive atom probe-P. J. Warren, A. Cerezo,

G. D. W. Smith

Digital field ion microscopy-S. J. Sijbrandij, K. F. Russell, R. C. Thomson, M. K. Miller 
An APFIM and TEM study of $\mathrm{Ni}_{4}$ Mo precipitation in a commercial $\mathrm{Ni}-28 \% \mathrm{Mo}-1.4 \% \mathrm{Fe}-0.4 \% \mathrm{Cr}$ wt. $\%$ alloy-

R. C. Thomson, N. Brown, J. S. Bates, K. F. Russell, M. K. Miller

High resolution analysis of elemental partitioning in nickel-base superalloy welds using atom probe field ion

microscopy-S. S. Babu, S. A. David, J. M. Vitek, M. K. Miller

Phase separation and precipitation in a $\mathrm{PH} 17-4$ stainless steel by prolonged aging at $400^{\circ} \mathrm{C}-\mathrm{M}$. Murayama,

Y. Katayama, K. Hono

Microstructural characterization of rapidly solidified ultrahigh strength aluminum alloys-D. H. Ping,

K. Hono, A. Inoue

Atom probe field ion microscopy of titanium aluminides-D. J. Larson,

M. K. Miller

Atom probe field ion microscopy of polysynthetically twinned titanium aluminide-D. J. Larson, M. K. Miller,

H. Inui, M. Yamaguchi

Atom probe studies of the nanochemistry of steels-G. D. W. Smith, A. Cerezo, T. J. Godfrey, J. Wilde,

F. M. Venker

The role of atom probe in the study of nickel base superalloys-D. Blavette 106

APFIM and HREM studies of nanocomposite soft and hard magnetic materials-K. Hono, D. H. Ping,

M. Ohnuma

The atom-probe field ion microscope: Applications in surface science-G. L. Kellogg 108

Field ion microscopy of multilayer film devices-D. J. Larson, A. K. Petford-Long, A. Cerezo 110

APFIM studies of interfaces: Structure and composition-H. Nordén 112

Clustering and segregation of $\mathrm{Ag}$ and $\mathrm{Mg}$ atoms in the nucleation and growth stage of $\Omega$ and $\mathrm{T}_{1}$ precipitates in Al-Cu(-Li) alloys--M. Murayama, L. Reich, K. Hono 116

APFIM investigation of segregation in a nickel base alloy-M. Thuvander, K. Stiller 118

\section{COMPOSITIONAL MAPPING WITH HIGH SPATIAL RESOLUTION}

Compositional imaging rediscovered: What's new/what's not?-M. S. Isaacson 120

Interdisciplinary development of EELS compositional mapping-R. D. Leapman 122

Direct imaging of trace elements, isotopes, and molecules using mass spectrometry-R. W. Linton 124

Multispectral imaging in light microscopy-K. R. Spring 126

Quantitative energy-filtering transmission electron microscopy (EFTEM) in materials science-F. Hofer,

W. Grogger, P. Warbichler

Polarization modulation differential interference contrast (Pol Mod DIC) microscopy: An improvement for video microscopy-N. S. Allen, D. Moxley, D. Collings, G. Holzwarth

Transmission electron holography of a GaN/Al $\mathrm{Ga}_{1-\mathrm{x}} \mathrm{N}$ heterostructure-Y. C. Wang, C. Kisielowski,

E. C. Nelson, M. A. O'Keefe

Strategies for combining elemental distribution data derived from multiple images and samples-M. E. Cantino,

J. G. Eichen

Quantitative composition and thickness mapping with high spatial resolution by XEDS in a $300 \mathrm{kV}$ FEG-AEMM. Watanabe, D. B. Williams 
Compositional imaging at the sub- $2 \AA$ level using a $200 \mathrm{kV}$ Schottky field emission transmission electron microscope-E. M. James, N. D. Browning, A. W. Nicholls, M. Kawasaki, S. Stemmer, Y. Xin, G. Duscher .. 138 Quantitative compositional mapping of phase separation in thin polymer films-D. A. Winesett, H. Ade,

A. P. Smith, S. Qu, S. Ge, M. Rafailovich, S. Sokolov

Morphological and chemical characterization of a mechanically alloyed rubber toughened PMMA with x-ray spectromicroscopy-A. P. Smith, H. Ade, R. J. Spontak, C. C. Koch

$\mathrm{X}$-ray microscopy analysis of the morphology of poly(ethylene terephthalate)/vectra blends produced by mechanical alloying-A. P. Smith, C. Bai, H. Ade, R. J. Spontak, C. M. Balik, C. C. Koch, C. K. Saw

Compositional characterization of an O-N-O layer in a dram using FE-TEM and EDS elemental mappingM. Kawasaki, T. Oikawa, K. Ibe, K. H. Park, M. Shiojiri, M. Kersker .....

Compositional characterization of an O-N-O layer in a dram using FE-TEM and energy filtered elemental mapping-M. Kawasaki, T. Oikawa, K. Ibe, K. H. Park, M. Shiojiri, M. Kersker

Compositional characterization of an O-N-O layer in a dram using FE-(S)TEM and EELS-M. Kawasaki,

T. Oikawa, K. Ibe, K. H. Park, M. Shiojiri, M. Kersker

EFTEM and STEM EELS spectrum imaging-J. A. Hunt, R. H. Harmon

History and cross-disciplinary perspective of compositional imaging and mapping with NEXAFS microscopyH. Ade

Industrial and clinical applications of infrared spectroscopic imaging using focal-plane arrays-L. H. Kidder,

I. W. Levin, E. N. Lewis

Interfacial segregation and concentration profiles by energy-filtered transmission electron microscopy: Issues and guidelines-J. Bentley

Compositional mapping by scanning electron microscopy with energy dispersive X-ray spectrometry:

Recognizing facts and artifacts-D. E. Newbury, D. S. Bright

\section{YEARS OF ENERGY DISPERSIVE SPECTROMETRY IN MICROANALYSIS}

Going nondispersive-K. F. J. Heinrich

EDS from then till now-A chronology of innovation-J. J. Friel

$\mathrm{Si}(\mathrm{Li})$ and HPG detectors: Recent measurements-R. A. Sareen, T. Nashashib

The impact of EDS in materials science microanalysis-D. B. Williams

The impact of biological microanalysis on analytical electron microscopy-A. P. Somlyo 170

The next generation of EDS: Microcalorimeter EDS with $3 \mathrm{eV}$ energy resolution-J. M. Martinis, K. D. Irwin,

D. A. Wollman, G. C. Hilton, L. L. Dulcie, N. F. Bergren

Superconducting tunnel junction spectrometers for high resolution energy dispersive spectroscopy-

C. A. Mears

High resolution X-ray spectroscopy at room temperature-L. Strüder, P. Lechner, P. Leutenegger, T. Schülein .. 176

Application of $\mathrm{x}$-ray optics to energy dispersive spectroscopy-J. J. McCarthy, D. J. McMillan

The use of energy dispersive $\mathrm{x}$-ray microanalysis in the geological sciences: 30 years of heavy and creative

application-J. T. Armstrong

$\mathrm{X}$-ray energy dispersive spectroscopy in the environmental scanning electron microscope-J. F. Mansfield,

B. L. Pennington 
The analysis of particles with energy dispersive x-ray spectroscopy (EDS)-J. A. Small, J. A. Armstrong,

D. S. Bright, B. B. Thorne

Energy dispersive spectrometry in the AEM-J. R. Michael ................................................................................. 186

Low beam energies for EDS chemical microanalysis in the SEM (LVEDS)_E. D. Boyes ……………................... 188

Low voltage $\mathrm{x}$-ray microanalysis of bulk bio-organic samples-P. Echlin ................................................................. 190

EDS of thin biological specimen in the study of time-dependent physiological processes-M. F. Wendt-Gallitelli,

T. Voigt, M. Schultz, F. Rudolf, G. Isenberg ...

"Standardless" quantitative analysis by electron-excited energy dispersive $\mathrm{x}$-ray spectrometry: What is its proper role?-D. E. Newbury

Microcalorimeter EDS measurements of chemical shifts in Fe compounds-D. A. Wollman, D. E. Newbury,

G. C. Hilton, K. D. Irwin, L. L. Dulcie, N. F. Bergren, J. M. Martinis

Unprecedented performance improvement for thermoelectrically cooled $\mathrm{Si}(\mathrm{Li})$ detector for EDS-S. Barkan,

K. F. Ihrig, M. B. Abott

A new EDS equipment (GEM detector with SuperATW window) and a correction for Si-contamination

improve the quantitative electron probe microanalysis of biological cryosections-M. Schultz, F. Rudolf,

M. F. Wendt-Gallitelli

Multivariate statistical analysis of particle x-ray spectra-I. M. Anderson, J. A. Small

Extracting chemical information from energy-dispersive $\mathrm{x}$-ray spectra by multivariate statistical analysis

(MSA)-M. Saunders, E. S. K. Menon, D. J. Chisholm, A. G. Fox

$\mathrm{X}$-ray emission from porous materials: New results-R. Gauvin 206

Statistical consideration in EDS microanalysis-E. Lifshin 208

Measuring performance of EDX systems-P. Statham 210

Trace element quantitation in biological $x$-ray microanalysis-R. D. Leapman, C. R. Swyt-Thomas,

D. v. Agoston, N. Pivovarova, S. B. Andrews

Quality assurance of energy dispersive spectrometry systems-E. B. Steel, R. B. Marinenko 214

\section{PROBLEM ELEMENTS AND SPECTROMETRY PROBLEMS IN X-RAY MICROANALYSIS}

Problem elements and spectrometry problems in $\mathrm{x}$-ray microanalysis: The black holes of the periodic table-

J. T. Armstrong

Extracting low energy $x$-ray peaks from EDS and WDS spectra-R. L. Myklebust, D. E. Newbury

Analyzing the light elements in an electron probe microanalyzer-G. F. Baston, H. J. M. Heijligers

Using quantitative iteration to correct for pathological spectral interferences-J. J. Donovan

Analyzing $\mathrm{Mg}$ and $\mathrm{Fe}$ in olivines, pyroxenes, and garnets: Systematic discrepancies-P. Carpenter,

J. Armstrong

Limits of analytical accuracy for two critical semiconductors systems: $(\mathrm{Al}, \mathrm{Ga})(\mathrm{As}, \mathrm{P})$ and $(\mathrm{In}, \mathrm{Ga})(\mathrm{As}, \mathrm{P})$ -

J. T. Armstrong

Beam induced composition modifications during electrom beam microanalysis_-D. G. Howitt, D. L. Medlin ..... 228

$\mathrm{k}$-factor standards for low-z quantification-R. Egerton, M. Malac

The role of Monte Carlo calculations in quantitative analysis-E. Lifshin, L. A. Peluso, R. Gauvin 
Fluorescent spectroscopy of mineral and material samples-C. M. MacRae, I. R. Harrowfield, N. Wilson,

M. Yoshiya, P. Fazey, S. Peacock, L. de Yong, H. Adachi

\section{QUANTITATIVE MICROANALYSIS}

Electron microprobe reference materials for geologic analysis-A need for developing strategy-E. Jarosewich ... 238

A Basalt glass standard for multiple microanalytical techniques-G. P. Meeker, J. E. Taggart, Jr., S. A. Wilson ... 240

Electron probe evaluation of heterogeneity in the certification of NIST standard reference materials for microanalysis-R. B. Marinenko, S. Leigh

Characterization of archaeological ceramics using scanning electron microscopy and electron microprobe analysis-M. N. Spilde, N. H. Olsen, N. Creager

A microprobe study to differentiate bulk chemical data by neutron activation analysis on Guatemalan pottery-

L. Ross, J. Cogswell, H. Neff

Critical role of EMPA in discovery of a new lunar mineral-M. G. Snow, D. T. Vaniman 248

\section{NEW TRENDS IN SCANNING ELECTRON MICROSCOPY AND MICROANALYSIS}

The effect of mass in electron-solid interactions and the mystery of the "Heinrich kink"-J. J. Donovan,

N. E. Pingitore, Jr.

Factors affecting the performance of backscattered electron detectors at low beam accelerating voltages in

SEM-V. N. E. Robinson

Chemical quantitative analysis of small precipitates in the FE-SEM using the energy distribution of backscattered electrons-R. Gauvin

Secondary electron detectors, image quality \& contrast-D. Scharf 256

Refining equipment for high resolution in-lens cryo-SEM-R. P. Apkarian, S. Lee, J. Keiper 258

Image formation with upper and lower secondary electron detectors in the low voltage field-emission SEM-

J. Liu

Quantitative elemental analysis of the components of $\mathrm{Pb}$ exposed cells of Plectonema boryanum using regular and overplus cells: An energy dispersive x-ray spectroscopy study-J. J. Goldberg, T. E. Jensen

Wool and cashmere fiber identification study using scanning electron microscopy-J. D. Baker, H. P. Lentz,

D. G. Kritikos, F. H. Schamber, R. J. Lee

Montages link microscopic to macroscopic information in concrete analysis-A. Doerr, S. Badger, P. Brown,

S. Sahu 266

Design and construction of a quantitative uniaxial straining stage for the environmental SEM-J. F. Mansfield,

M. D. Thouless, J. A. Stefano, J. Holbrook 268

In situ mechanical testing of dry and hydrated cellular materials in the environmental scanning electron

microscope (ESEM)-D. J. Stokes, A. M. Donald

Multivariate statistical analysis of low-voltage EDS spectrum images-I. M. Anderson 
Use of the disk-of-least-confusion in X-ray microanalysis-E. A. Kenik, S. X. Ren

Quantifying SEM resolution and performance-D. C. Joy, E. Völkl

Microstructure and microtexture in Nb-silicide based composites-B. P. Bewlay, J. A. Sutliff

Investigation of medium to high strain deformation micro-structures using an automated electron

backscattering pattern (EBSP) system-A. Godfrey, N. C. Krieger Lasssen, D. A. Hughes, D. J. Jensen

Evaluation of boron nitride coated Nextel $312^{\mathrm{TM}}$ Fiber/Blackglas $^{\mathrm{TM}}$ composites using an environmental SEM-

R. L. Schalek, J. Helmuth, L. T. Drzal

'Cool ESEM'-Imaging ice-containing systems at freezer temperatures-A. L. Fletcher, T. H. Keller, B. L. Thiel,

A. E. Eddy, A. M. Donald

ESEM study of film formation in latices polymerised in presence of starch-N. Stelmashenko, A. M. Donald ..... 286

Secondary electron contrast in molecular liquids-B. L. Thiel, D. J. Stokes, A. M. Donald .................................. 288

Electrons, ions and cathodoluminescence in the environmental SEM-B. J. Griffin ................................................290

Charge contrast: Some ESEM observations of a new/old phenomenon-E. Doehne ............................................. 292

Operating conditions for quantitative $\mathrm{x}$-ray analysis in the environmental SEM-R. A. Carlton, C. E. Lyman,

J. E. Roberts

Optimisation of the S.E. signal to background ratio in ESEM-T. H. Keller, B. L. Thiel, A. M. Donald ............... 296

Beam size in the environmental SEM: A comparison of model and experimental data-S. A. Wight ................... 298

Using secondary electron contrast for imaging water-oil emulsions in the environmental SEM (ESEM)-

D. J. Stokes, B. L. Thiel, A. M. Donald

\section{SCANNED PROBE MICROSCOPY: MUCH MORE THAN JUST BEAUTIFUL IMAGES}

Topographic comparison of G-wire DNA imaged by hydration scanning tunneling and atomic force microscopy as a function of humidity-D. Janigian, E. Morales, T. Muir, B. Garcia, J. Vesenka

Ordering of a functional molecules on a flat surface as evidenced by scanning probe microscopies: The case of a di-alkyl amino group-C. Gorman, I. Touzov, R. Miller

Langmuir-Blodgett film stability via atomic force microscopy-D. Y. Takamoto

Atomic force microscopy studies of microstructure and properties of self assembled monolayers-J. R. Santiago,

E. B. Troughton, R. A. Dennis, P. E. Russell

Biometrology? Finding biological, pathological, diagnostic meaning from critical length-scale measurements-

M. J. Allen, V. B. Elings

A novel preparation method for high resolution AFM introduced with 2D-streptavidin crystals grown on a biotin-lipid monolayer-S. Scheuring, D. J. Müller, P. Ringler, J. B. Heymann, A. Engel ....

Development of polarization modulation near-field scanning optical microscope and its application to mapping defect-induced birefringence in $\mathrm{SrTiO}_{3}$ bicrystals-J. W. P. Hsu, E. B. McDaniel, S. C. McClain

Using a moderate vacuum, hot/cryo-stage equipped AFM for in-situ observation of $\alpha$-phase growth in $60 \mathrm{Sn} 40 \mathrm{~Pb}$ hypoeutectic solder-D. N. Leonard, P. E. Russell

An in situ scanning tunnelling microscopy study of the adsorption of the aurocyanide ion onto highly orientated pyrolytic graphite-G. E. Poinen, S. M. Thurgate

Diamond indenter shaping using focused ion beam-J. R. Phillips, K. F. Jarausch, T. J. Stark, J. E. Houston, D. P. Griffis, P. E. Russell 
The SPM study of surface healing due to mass transport in the liquid-like layer of ice-D. M. Trickett,

V. F. Petrenko

Magnetically-oscillated probe AFM for imaging and stiffness measurements at the liquid-solid interface-

S. M. Lindsay, W. Han, N. Tao

TEM analysis of deformation zones in FIB-prepared samples of microploughed gold (100) and (111) surfaces-

R. D. Day, R. M. Dickerson, C. J. Maggiore, P. M. Brooks, P. E. Russell, T. Woodward, C. B. Carter 326

Comparative surface study of atomic images with variable temperature UHV-AFM and STM-M. Iwatsuki,

K. Suzuki, S. Kitamura, M. Kersker 328

Scanning Kelvin force and capacitance microscopy applications-R. J. Kline, J. F. Richards, P. E. Russell 330

The surface morphology and characterisation of electronic properties of boron implanted microwave plasma

CVD diamond films by atomic force and scanning tunneling microscopies-A. G. Fitzgerald, Y. Fan, P. John,

C. E. Troupe, J. I. B. Wilson

Using AFM phase lag data to identify microconstituents with varying values of elastic modulus-D. N. Leonard,

A. D. Batchelor, P. E. Russell

Nanomanipulation for material properties, substrate interactions and devices-R. Superfine, M. R. Falvo,

G. J. Clary, S. Paulson, R. M. Taylor II, V. Chi, F. P. Brooks Jr., S. Washburn 336

\section{ELECTRON DIFFRACTION AND SCATTERING}

Electron scattering in diamond as a function of thickness-D. C. Bell 338

Absorption potential for dynamic electron diffraction: A revisit-Z. L. Wang, C. Zhang 340

Analysis of selected area diffraction patterns with WinJade-S. D. Walck, P. Ruzakowski-Athey 342

Computer analysis of electron diffraction from thin films-W. MoberlyChan, R. Kilaas, L.-H. Chan, T. Nolan,

P. Dorsey, W. Cao, M. Lu, M. Gopal, T. Yamashita 344

\section{NOVEL X-RAY METHODS: FROM MICROSCOPY TO ULTIMATE DETECTABILITY}

Application of synchrotron radiation to analysis of both contamination and structure of silicon surfaces and interfaces-P. Pianetta, S. Brennan

Trace element detection by x-ray fluorescence-M. C. Madden, R. Wong, D. C. Wherry ………………………... 348

High resolution $\mathrm{x}$-ray microscopy of frozen hydrated samples-G. Schneider

High spatial resolution soft $\mathrm{x}$-ray microscopy and microanalysis of thick and hydrated materials-W. Meyer-Ilse,

J. T. Brown, C. Magowan, J. Yeung, K. E. Kurtis, P. Monteiro, B. P. Tonner, K. Nealson, S. Lelièvre,

C. Larabell

Imaging, spectroscopy and tomography of frozen hydrated specimens with the cryo scanning transmission

x-ray microscope at the NSLS-J. Maser, C. Jacobsen, Y. Wang, A. Osanna, B. Winn, J. Kirz

Mapping the organic and inorganic components of normal and osteoporotic bone using NEXAFS-C. J. Buckley,

N. Khaleque, S. J. Bellamy, G. Dermody, M. Robins, X. Zhang 356

Mephisto: A novel synchrotron imaging photoelectron spectromicroscope-G. De Stasio 358

xxxiv 
Quantitative non-interferometric x-ray phase imaging-K. A. Nugent, D. Paganin, J. Tiller, B. Allman

A state-of-the-art x-ray microprobe and its applications at the advanced photon source-W. Yun, Z. Cai, B. Lai,

J. Maser, D. Legnini

Spatially-resolved x-ray absorption fine structure (XAFS) spectroscopy using undulator radiation focused by

dynamically-bent elliptical mirrors-S. R. Sutton, P. E. Eng, M. L. Rivers, M. Newville

Precise $\mathrm{x}$-ray microfluorescence measurements of $\mathrm{Sr} / \mathrm{Ca}$ ratios in corals for paleotemperature analysis-

N. E. Pingitore Jr., T. Pogue

Applications of laboratory-based $\mathrm{x}$-ray microfluorescence analysis in archaeometry-N. E. Pingitore Jr.,

J. D. Leach, A. Iglesias, C. G. Sampson, D. L. Carmichael, J. A. Peterson

$\mathrm{X}$-ray radiation damage of polymers in a scanning transmission $\mathrm{x}$-ray microscope-T. Coffey, $\mathrm{H}$. Ade,

S. Urquhart, A. P. Smith

Characterizing inhomogeneous deformation substructure in large single crystals by microscopy and XRD-A

synergystic analysis-P. W. Kingman

X-ray microscopy developments at the ESRF-B. Kaulich, S. Oestreich, R. Barrett, J. Susini

Bragg and Fresnel diffraction imaging using highly coherent $\mathrm{x}$-rays-P. Cloetens, J. Baruchel, J. P. Guigay,

W. Ludwig, L. Mancini, P. Pernot, M. Schlenker

Recent developments in monochromatic microprobe $\mathrm{x}$-ray fluorescence (MMXRF)_Z. W. Chen,

D. B. Wittry

Comparing elemental sensitivities obtained with an aperture and a monolithic polycapillary optic using a commercial micro-X-ray fluorescence (MXRF) instrument-C. G. Worley, L. P. Colletti, G. J. Havrilla 380

\section{ADVANCES IN INSTRUMENTATION AND PERFORMANCE}

High resolution transmission electron microscopy at zero $\mathrm{C}_{\mathrm{s}}-\mathrm{M}$. A. O'Keefe

First application of a spherical-aberration corrected microscope material science-B. Kabius, K. Urban,

M. Haider, S. Uhlemann, E. Schwan, H. Rose

Experimental gun brightness measurements on a $300 \mathrm{kV} \mathrm{CFEG-N.} \mathrm{J.} \mathrm{Zaluzec,} \mathrm{A.} \mathrm{Nicholls}$

Measuring and tuning TEM energy filter performance-H. Brink, G. Kothleitner, M. K. Kundmann

Modification of a conventional TEM (CTEM) for Lorentz microscopy-M. Wall, S. Bajt, C. Cerjan

On the effects of spherical aberration and aperture misalignment on the formation of small electron probes-

A. J. Garratt-Reed, G. Cliff, P. B. Kenway

Energy filtering imaging of thick biological specimens with in-column "Omega"-filter microscopes-

M. H. Ellisman, G. Y. Fan, T. Honda, T. Kanayama, M. Kersker

A new $200 \mathrm{kV}$ energy filter field emission transmission electron microscope-T. Kaneyama, K. Tsuno,

T. Honda, M. Kersker, K. Tsuda, M. Terauchi, M. Tanaka

The CM120-BioFilter: Digital imaging of frozen hydrated specimens and elemental mapping-U. Lücken,

A. F. de Jong, M. Kundmann, D. Cherny, R. Leapman

Development of a Philips cryo-TEM provided with a liquid helium cooled tilt stage and a vacuum transfer system-R. Wagner, A. F. de Jong, A. G. Koster, R. Morrison, F. Tothill, U. Lücken

Development of a side entry high tilt cryotransfer stage for tomographic applications-B. L. Armbruster,

R. Zolkowski, P. R. Swann 
Magnetic deflecting microscopy: A novel visualizing method of magnetic stray fields for thick or non-transparent magnetic TEM samples-V. V. Volkov, Y. Zhu

Development of high resolution FE-SEM (8"FE-SEM) for 8-inches wafer inspection-K. Ohara, C. Nielsen, M. Saito 406

Quantitative visible-light and electron phase microscopy-A. Barty, K. A. Nugent, D. Paganin, A. Roberts 408 An infinity corrected all-reflecting microscope for infrared microspectrometry-J. A. Reffner, S. H. Vogel .......... 410

Isotopic measurements of inorganic material by time-of-flight SIMS-A. J. Fahey 412

\section{NEW DEVELOPMENTS IN MULTI-PHOTON EXCITATION MICROSCOPY}

Second harmonic generation imaging (SHG) in the non-linear optical microscopy of living cells-

P. J. Campagnola, L. M. Loew

Quantitative immunocytochemistry of proteins using 2-photon microscopy and digital image analysis-H. Wan,

C. Soeller, D. R. Garrod, C. Robinson, M. B. Cannell

High-QE photodetector for laser confocal-J. Pawley, M. Blouke, J. Janesick

In-depth imaging using two-photon excitation microscopy-H. C. Gerritsen, J. M. Vroom, C. J. de Grauw .........

Visualizing neuronal structure by combining GFP-transfection with 2-photon microscopy in living brain slices-

H. L. W. Horch, L. C. Katz

Video-rate scanning two-photon excitation fluorescence microscopy-G. Y. Fan, H. Fujisaki, R.-K. Tsay,

R. Y. Tsien, M. H. Ellisman

\section{UNIQUE APPROACHES IN IMAGING, COMPUTATION AND COMMUNICATION FOR CHARACTERIZATION OF THE 3D CELL \& ORGANELLES I}

Tomographic reconstruction of the hair cell ribbon synapse-D. Lenzi, J. W. Runyeon, J. Crum, M. H. Ellisman, W. M. Roberts

Crista junctions of mitochondria visualized by electron tomography-G. A. Perkins, J. Y. Song, L. Tarsa,

C. McCarty, T. J. Deerinck, M. H. Ellisman, T. G. Frey

Electron microscopic tomography of cellular organelles: Chemical fixation vs. cryo-substitution of rat-liver mitochondria-C. A. Mannella, K. Buttle, K. Tessitore, B. K. Rath, C. Hsieh, D. D’Arcangelis, M. Marko ....

3D structure of periodic cubic-phase inner membranes in mitochondria of the amoeba Chaos carolinensis-

Y. Deng, M. Mieczkowski, M. Marko, K. Buttle, B. K. Rath, C. A. Mannella

Electron tomographic studies of a large macromolecular assembly preserved in vitreous ice: The yeast spindle pole body core- E. Bullitt

The centrosome: Three-dimensional structure of a cell organelle at $40 \mathrm{~A}$ resolution obtained by electron-

tomography-T. Ruiz, M. Radermacher, B. Rath, C. Rieder, M. Bornens

The three dimensional organization of smooth muscle: Information from serial section reconstructions-

R. A. Horowitz, C. M. Powers, P. Valero, R. Craig 
Correlated 3D light and electron microscopy of large, complex structures: Analysis of transverse tubules in heart failure-M. E. Martone, A. Thor, S. J. Young, M. H. Ellisman ..

Quantitative image processing in $3 \mathrm{D}-\mathrm{U}$. Skoglund

A transportable multiple oblique illumination system which retrofits to conventional optical microscopes to provide high-definition real time 3-dimensional imaging-G. L. Greenberg, A. Boyde

Fluorescent indicators for calcium based on green fluorescent proteins (GFPs) and calmodulin-A. Miyawaki,

J. Llopis, R. Heim, J. M. McCaffery, J. A. Adams, M. Ikura, H. Fujisaki, G. Y. Fan, M. H. Ellisman,

R. Y. Tsien

Confocal imaging of both mitochondrial and cytosolic free $\mathrm{Ca}^{2+}$ in cardiac myocytes co-loaded with Rhod 2 and

Fluo 3: Inhibition by ruthenium red of mitochondrial but not cytosolic $\mathrm{Ca}^{2+}$ transients-D. R. Trollinger,

W. E. Cascio, J. J. Lemasters

Correlative confocal and electron microscopy of the Connexin43 gap junction protein in NRK cells: Balancing

fixation conditions, cell permeabilization, antigen-antibody interaction and cell ultrastructure-G. Sosinsky,

M. Martone, G. Hand, L. Musil, M. Ellisman

Using animation to enhance 3D visualization: A strategy for a production environment- $\mathrm{M}$. T. Dougherty,

W. Chiu

\section{HIGH RESOLUTION PROTEIN STRUCTURES FROM ELECTRON CRYSTALLOGRAPHY}

Atomic model of tubulin by electron crystallography-E. Nogales, K. H. Downing

Structure and action of molecular tracks and motors-R. A. Milligan

Actin filaments decorated with cytoskeletal proteins-D. Hanein, S. Goldsmith, W. Lehman, R. Craig,

I. Correia, P. Matsudaira, D. J. DeRosier, S. C. Almo

Crystallographic reconstruction of the acrosomal process from Limulus polyphemus sperm-M. B. Sherman,

J. Jakana, S. Sun, P. Matsudaira, W. Chiu, M. F. Schmid

Structure of the calcium pump from sarcoplasmic reticulum at $8 \AA$ resolution: Architecture of the transmembrane helices and localization of the binding site for thapsigargin-P. Zhang, C. Toyoshima, K. Yonekura,

G. Inesi, M. Green, D. L. Stokes

Structure of a recombinant gap junction channel at $7 \AA$ resolution-V. M. Unger, D. W. Entrikin, X. Guan,

N. M. Kumar, N. B. Gilula, M. Yeager

Electron crystallography of a prokaryotic potassium channel-H. X. Sui, H. L. Li, S. Ghanshani, S. Lee,

P. J. Walian, C. L. Wu, K. G. Chandy, B. K. Jap

\section{SHARED RESOURCES AND USER FACILITIES: ACCESS TO INSTRUMENTATION}

The UCF/Cirent materials characterization facility-L. A. Giannuzzi, J. B. Bindell

Shared research equipment at Oak Ridge National Laboratory-N. D. Evans, E. A. Kenik, M. K. Miller 


\section{MICROSCOPY AND MICROANALYSIS IN THE “REAL WORLD”}

Analytical light microscopy: Examples of practical problem-solving and efficiency in pharmaceutical quality control and formulation-D. A. Stoney, W. C. McCrone

474

Microscopical examination of indoor dusts-J. R. Millette, P. Few, T. J. Hopen ........................................................ 476

Microscopy in pharmaceutical development-R. A. Carlton

Analysis of in-situ converted chrysotile asbestos fibers in sprayed on fireproofing-R. L. Sabatini, T. Sugama,

L. Petrakis

Production microscopy: A new paradigm-R. J. Lee

Population studies of titanium-bearing inclusions in AISI 316L using automated image analysis with scanning electron microscopy/electron dispersion spectroscopy (SEM/EDS)-S. R. Collins, M. Plishka

Microanalysis of thermal-sprayed titanium anodes for cathodic protection of reinforced concrete bridges-

W. K. Collins, S. D. Cramer, B. S. Covino, Jr., G. R. Holcomb, S. J. Bullard, R. D. Govier, R. D. Wilson,

G. E. McGill

Cathodoluminescence microscopy of architectural paint samples-T. J. Hopen, R. S. Brown, R. K. Wheeles,

W. Stocklein

Applying microscopy in forensic science-H. C. Lee

High resolution FIB as a general materials science tool-M. W. Phaneuf, J. Li, T. Malis

Low energy $\mathrm{x}$-ray transmission images by using a microfocus $\mathrm{x}$-ray tube and a Be-window $\mathrm{x}$-ray image intensifier

(XRII)-H. Konuma, K. Kuroki, K. Kurosawa, N. Saitoh

Examination of the surface of a MALDI-FTMS probe tip using SEM and determination of detection limits for

poly(ethylene glycol)-S. H. Wood, S. J. Pastor, C. L. Wilkins

Binding of polychlorinated biphenyls to sediment-W. F. Tivol, A. C. Casey, X. Liu, B. Bush

Morphological identification of indicator viruses from a ground water aquifer recharged with reclaimed

wastewater-J. R. Stewart, M. D. Sobsey, T. M. Gambling, J. L. Carson

Measurements of fine volcanic ash via stereoscopy in the scanning electron microscope-O. P. Mills,

W. I. Rose, C. M. Riley

Structural changes of soot particulates as shown by HRTEM and image analysis-Á. B. Palotás, D. C. Bell,

L. C. Rainey, J. B. Vander Sande

Corrosion product identification by micro-Raman and Mössbauer spectroscopy-F. Adar, B. Lenain,

D. C. Cook, S. J. Oh

Raman microprobe study of the visible and near-infrared excited fluorescence spectra of glasses examined as

potential Raman intensity calibration standards-E. S. Etz, S. J. Choquette, W. S. Hurst, D. H. Blackburn ...

Relationship between TEM microstructures of A1 films and reflectance in color display tubes-S. J. Lee,

E. S. Hwang, T. Dolukhanyan, C. M. Sung

Solidification behavior of a 319 aluminum alloy-W. T. Donlon, L. A. Godlewski, J. W. Zindel 512

Characterization of age hardening in a $319 \mathrm{Al}$ alloy-R. Jahn, W. T. Donlon, J. E. Allison 514

Fractographic evaluation of thermally stressed single crystal sapphire-S. D. Wajer, P. H. Cohen 516

Application of SEM, TEM and CBED techniques for compound identification in stress corrosion cracking

failure-R. Caballero, A. Quintero

\section{xxxviii}


Scanning electron microscopy/energy dispersive $\mathrm{x}$-ray spectrometry (SEM/EDS): The last step in the

microanalysis of particulate matter isolates—R. J. Maxwell, M. A. Smith, D. S. Aldrich .................................... 520

Industrial applications of scanning probe microscopy—S. Magonov ................................................................ 522

New microscopy techniques for IC defect localization-E. Cole Jr. ................................................................ 524

Relocating features across microanalytical instrumentation-W. H. Powers, Jr., F. H. Schamber ............................ 526

"Real-world" microscopy: Understanding environment-sensitive behavior of Ni-base welds-M. G. Burke,

R. J. Wehrer, C. M. Brown ................................................................................................................. 528

Characterization of solid-state vortices associated with the friction-stir welding of copper to aluminum-

R. D. Flores, L. E. Murr, E. A Trillo _........................................................................................................ 530

Terra Incognita: Spectra from edges and elements not in the EELS Atlas-J. A. Fortner, E. C. Buck ..................... 532

\section{METALS AND ALLOYS}

Incommensurate structures in rhenium disilicide-A. Misra, F. Chu, T. E. Mitchell

Defects in Nb-Cr-Ti C15 Laves phase alloys-P. G. Kotula, C. B. Carter, K. C. Chen, D. J. Thoma, F. Chu,

T. E. Mitchell

Nucleation of the $\alpha / \gamma$ massive phase transformation in titanium-48at\% aluminum-J. E. Wittig,

W. H. Hofmeister

Microstructure of the die-upset $\mathrm{Nd}(\mathrm{Pr})-\mathrm{Fe}-\mathrm{B}$ hard magnets studied by magnetic and high resolution

transmission microscopy-V. V. Volkov, Y. Zhu, L. H. Lewis, D. O. Welch

Characterization of corrosion scales on $\mathrm{Fe}-13 \mathrm{Cr}$ stainless steel-S. Subramanian, S. Ling, T. A.

Ramanarayanan

The Microstructure of oxidized consolidated nanocrystalline NiAl-T. Chen, J. M. Hampikian

\section{MICROSCOPY OF CERAMICS AND MINERALS}

Microstructure and microchemistry of Y-doped $\alpha-\mathrm{Al}_{2} \mathrm{O}_{3}-\mathrm{M}$. A. Gülgün, M. L. Mulvihill, V. Putlayev,

M. Rühle

Stress-induced phase transformations in SiC - P. Pirouz ....................................................................................

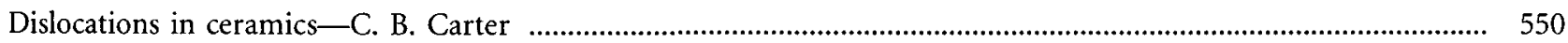

Statics and dynamics of "charged" interfaces in electroceramics-X. Lin, C. Murray, V. P. Dravid ........................ 552

Z-contrast imaging of ordered structures in $\mathrm{Pb}\left(\mathrm{Mg}_{1 / 3} \mathrm{Nb}_{2 / 3}\right) \mathrm{O}_{3}$ and $\mathrm{Ba}\left(\mathrm{Mg}_{1 / 3} \mathrm{Nb}_{2 / 3}\right) \mathrm{O}_{3}-\mathrm{Y}$. Yan, Z. Xu, D. Viehland,

S. J. Pennycook

Atomic scale structure-property relationships of defects and interfaces in ceramics-S. Stemmer, G. Duscher,

E. M. James, M. Ceh, N. D. Browning

The complementary nature of electron microscopy and ion channeling for the assessment of radiation damage evolution in ceramics-K. E. Sickafus

Interpreting uranyl mineral diffraction patterns-E. C. Buck

White lines in the iron $\mathrm{L}_{2,3}$ electron-energy-loss spectra of pyrite and greigite--S. C. Cheng, R. T. Wilkin 
TEM analysis of diamond films formed on $\mathrm{SiO}_{2}$ substrate by bias-enhanced nucleation-S. C. Cheng,

M. D. Irwin, C. Onneby, C. G. Pantano

Improved adhesion of the c-BN film by the post ion implantation: TEM and FTIR-C. Sung, S. Gunasekara,

E. S. Byon, S. W. Lee, S. R. Lee

Microstructural characterization of carbon fiber-reinforced laminated matrix composites of silicon carbide and

carbon-K. A. Appiah, Z. L. Wang, W. J. Lackey

Carbon-induced UV sensitivity in aluminum nitride-Y. Berta, R. A. Gerhardt 570

Structure characterization of colossal magnetoresistive oxides-Y. Berta, D. B. Studebaker, M. Todd,

T. H. Baum, Z. L. Wang

Observations of superlattice reflections associated with charge ordering in $\mathrm{Bi}_{0.2} \mathrm{Ca}_{0.8} \mathrm{MnO}_{3}$ with an energy-filter-

Y. Murakami, D. Shindo, K. Hiraga, T. Oikawa, M. Kersker

Microstructure of $\mathrm{PbTiO}_{3} / \mathrm{SrTiO}_{3}$ superlattice grown by MBE-W. Tian, J. C. Jiang, X. Q. Pan, C. D. Theis,

D. G. Schlom

Domain structure of epitaxial $\mathrm{SrRuO}_{3}$ thin films on (001) $\mathrm{LaAlO}_{3}$-J. C. Jiang, X. Q. Pan, Q. Gan, C. B. Eom ... Microstructure and strain relaxation of epitaxial $\mathrm{SrRuO}_{3}$ films-J. C. Jiang, X. Q. Pan, Q. Gan, C. B. Eom 578

Determination of the site occupancy of holmium in $\mathrm{SrTiO}_{3}$ by alchemi-S. C. Cheng, A. Hitomi,

C. A. Randall 582

Characterization of intergranular phases in tetragonal and cubic yttria-stabilized zirconia--N. D. Evans,

P. H. Imamura, J. Bentley, M. L. Mecartney 584

Electron energy-loss spectroscopy (EELS) of cerium and uranium oxidation states-L. P. Keller,

J. P. Bradley 586

Microstructure of $\mathrm{Nb}$ based $\mathrm{Al}_{2} \mathrm{O}_{3}$ composites-C. Scheu, G. Dehm, W. D. Kaplan, D. E. Garcia, N. Claussen ...

On devitrification of monticellite $\left(\mathrm{CaMgSiO}_{4}\right)$ films grown on (001)-oriented single-crystal MgO.-S. V. Yanina,

M. T. Johnson, Z. Mao, C. B. Carter 590

Defects in pseudo-orthorhombic anorthite on basal sapphire-Z. Mao, M. T. Johnson, C. B. Carter 592

The effect of an electric field on the reaction between oxides-M. T. Johnson, C. B. Carter 594

Image periodicities introduced by three-fold astigmatism in HRTEM images of $\alpha-\mathrm{Al}_{2} \mathrm{O}_{3}$ and related materials-

D. L. Medlin, J. E. Smugeresky, D. Cohen 596

Polytypic constraints for solid-state layer silicate transformation mechanisms via atomic-resolution transmission

electron microscopy-J. F. Banfield, T. Kogure 598

Heterogeneous oxidation and precipitation of aqueous $\mathrm{Mn}$ (II) at the Goethite surface: A SPM study-

J. Rakovan, M. F. Hochella, Jr. 600

Electron microscopy and microanalysis of metal phases in meteorites-D. B. Williams, J. I. Goldstein 602

Microstructures and microanalysis in ALH84001: Minerals or martians?--R. P. Harvey, J. Bradley,

H. Y. McSween, Jr. 604

\section{MICROSCOPY OF SEMICONDUCTING AND SUPERCONDUCTING MATERIALS}

Photo-electron emission microscopy of semiconductor surfaces-R. J. Nemanich, S. L. English, J. D. Hartman, W. Yang, H. Ade, R. F. Davis 606

In situ electron microscopy studies of surface dynamical processes- R. M. Tromp 608 
Near-field scanning optical microscopy studies of individual dislocations in relaxed GeSi films-J. W. P. Hsu,

M. H. Gray, Q. Xu

Holography measurement of mean inner potential of germanium-J. Li, M. R. McCartney, R. E. Dunin-

Borkowski, D. J. Smith

Local strain measurements in hexagonal systems-C. Kisielowski, O. Schmidt

Electron microscopy in the real semiconductor processing world-R. Anderson

The determination of copper composition profiles in semiconductor device aluminum interconnect

electromigration test lines using electron probe microanalysis (EMPA)-J. M. Oparowski, T. S. Sriram,

V. Ambrose

Electronic structure and conductivity mechanism in manganite thin films exhibiting colossal magnetoresistance-

K. M. Krishnan, H. Ju, C. Nelson

Transmission electron microscopy studies of tin oxide thin films grown on the sapphire substrate-L. Fu,

X. Pan

HRTEM study of interface structure of heteroepitaxially grown GaSe thin films on GaAs(100)--Z. R. Dai,

S. R. Chegwidden, F. S. Ohuchi

TEM observations of interfacial defects in MOCVD GaAs on single crystal Ge substrates-K. M. Jones,

M. M. Al-Jassim, J. M. Olson

Microstructural characterization of $\mathrm{GaN}$ on (0001) sapphire-Z. Mao, M. T. Johnson, C. B. Carter 628

TEM investigation of Co-Si thin films on $\mathrm{Si}_{1 \cdot x} \mathrm{Ge}_{\mathrm{x}} / \mathrm{Si}-\mathrm{A}$. F. Myers, P. T. Goeller, E. B. Steel, B. I. Boyanov,

D. E. Sayers, R. J. Nemanich

Microstructure of porous silicon thin films-Y. Berta, R. A. Gerhardt

Solid-phase epitaxial regrowth of GaAs by in-situ controlled intermediate phase decomposition-J. K. Farrer,

D. A. Caldwell, C. J. Palmstrøm, C. B. Carter 634

Inversion domain boundaries in AlN and GaN thin films- K. Dovidenko, S. Oktyabrsky, J. Narayan 636

AlN films grown by electric field induced flux of Al cations-M. T. Johnson, Z. Mao, C. B. Carter 638

Scanning capacitance microscopy of dopants in III-V semiconductors-D. V. Lang 640

Electron holography of semiconductor junctions-M. R. McCartney, J. Li 642

Scanning electron microscopy of dopants in semiconductors-D. Venables 644

Prospects for imaging of single dopant atoms in silicon by ADF stem-R. R. Vanfleet, J. Silcox 646

Direct transmission electron microscope observations of doping variations in InP-based semiconductor laser diodes-R. Hull

Microscale elemental imaging of semiconductor materials using focused ion beam SIMS-F. A. Stevie,

S. W. Downey, S. Brown, T. Shofner, M. Decker, T. Dingle, L. Christman

Direct imaging of device characteristics in a focused ion beam system-A. N. Campbell, J. M. Soden

A new method for pin point failure analysis using FIB combined analytical TEM-T. Kamino, T. Yaguchi,

H. Matsumoto, M. Tomita, H. Koike

Focused ion beam (FIB) milling damage formed during TEM sample preparation of silicon-D. W. Susnitzky,

K. D. Johnson

Microstructural characterization of heteroepitaxial SiGeC alloys-D. J. Smith, D. Chandrasekhar, T. Laursen,

J. W. Mayer, J. Huffman, McD. Robinson, E. T. Croke, A. T. Hunter 658

Direct observation of threading dislocations in $\mathrm{GaN}$ by high resolution Z-contrast imaging-Y. Xin,

N. D. Browning, S. J. Pennycook, P. D. Nellist, S. Sivananthan, J.-P. Faurie, P. Gibart 660 
Ge distribution in $\mathrm{Si}_{80} \mathrm{Ge}_{20}$ islands grown in the high mobility regime-R. D. Twesten, J. A. Floro, E. Chason ....

Atomic structure of twinned As precipitates in LT-GaAs-S. Ruvimov, Ch. Dicker, J. Washburn, Z. Liliental-

Weber

Templating effects on C54-TiSi ${ }_{2}$ formation in ternary reactions-A. Quintero, M. Libera, C. Cabral Jr.,

C. Lavoie, J. M. Harper

Microstructure of $\mathrm{Au} / \mathrm{Ti}$ ohmic contacts on n-GaN-R.-J. Liu, L. L. Smith, M. J. Kim, R. W. Carpenter,

R. F. Davis

Kinetics of the $\mathrm{C}$-axis aligned $\mathrm{YBa}_{2} \mathrm{Cu}_{3} \mathrm{O}_{7}$ thick film by a $\mathrm{BaF}_{2}$ process-L. Wu, Y. Zhu, V. F. Solovyov,

H. Wiesmann, M. Suenaga

Microstructure of YBCO/Co-PBCO/YBCO edge Josephson junctions-Y. Huang, B. H. Moeckly, K. Char,

K. L. Merkle

Crystallographical analysis of intermediate phases in $\mathrm{Bi}(2223) / \mathrm{Ag}$ tape-L. Wu, Y. Zhu, M. Suenaga 674

Structure of low- and high-angle grain boundaries in YBCO/MgO films-S. Oktyabrsky, R. Kalyanaraman,

K. Jagannadham, J. Narayan

Oxide structures: By hook or by crook-L. D. Marks, W. Sinkler, H. Zhang

Study of the hole distribution in oxide superconductors using a sensitive electron diffraction technique-

J. Tafto, L. Wu, Y. Zhu

The electronic structure and bonding of copper oxides by CBED and EELs-M. Y. Kim, J. Alvarez, J. M. Zuo,

J. C. H. Spence

Two-mirrors model: Some analytical solutions for generating the constrained coinsident-site-lattice and its

application to $\mathrm{Bi}_{2} \mathrm{Sr}_{2} \mathrm{Ca}_{1} \mathrm{Cu}_{2} \mathrm{O}_{8+\delta}$ grain boundaries-V. V. Volkov, Y. Zhu

Application of field-emission TEM to investigating flux pinning mechanism in superconductors-

A. Tonomura 686

The atomic-scale origins of grain boundary superconducting properties-S. J. Pennycook, J. Buban,

C. Prouteau, M. F. Chisholm, P. D. Nellist, N. D. Browning 688

Investigation of the local superconducting properties at grain boundaries in high-Tc superconductors-

C. Prouteau, G. Duscher, N. D. Browning, S. J. Pennycook, D. Verebelyi, D. K. Christen, M. F. Chisholm,

D. P. Norton 690

Anisotropy of electronic structure and transport properties of oxide superconductors-V. P. Dravid 692

\section{NANOPHASE AND AMORPHOUS MATERIALS}

Structure in amorphous network solids and its evidence in electron diffraction-L. W. Hobbs

Observation and theoretical prediction of structure in amorphous carbon and related materials-

D. R. McKenzie, D. G. McCulloch, C. M. Goringe, A. R. Merchant

Silicon carbide amorphization by electron irradiation-J. Bentley

RDF analysis of radiation-amorphized $\mathrm{SiC}$ using a field emission scanning electron microscope-D. C. Bell,

A. J. Garratt-Reed, L. W. Hobbs

Fluctuation microscopy: A new class of microscopy techniques for probing medium range order in amorphous materials-J. M. Gibson, M. M. J. Treacy, P. M. Voyles 
Experimental and theoretical characterisation of structure in thin disordered films-D. G. McCulloch,

D. R. McKenzie, D. J. H. Cockayne, C. M. Goringe

Extended electron loss fine structure analysis of silicon-K edges using an imaging filter-J. A. Fortner,

E. C. Buck, D. M. Strachan, N. J. Hess

Graphitic disks or polygons? Faceting of graphite disks-A. Krishnan, E. Dujardin, T. W. Ebbesen,

M. M. J. Treacy

Microstructure in nanophase and amorphous boron-based thin films-D. L. Medlin, K. F. McCarty,

D. A. Buchenauer, D. Dibble, D. B. Poker

An investigation into beam damage of mesoporous materials - C. F. Blanford, J. Bentley, A. Stein,

C. B. Carter

712

A study of amorphous chalcogenides by electron microscopy and analysis-A. G. Fitzgerald, K. Mietzsch 714

A BCC superlattice of passivated gold nanocrystals-S. A. Harfenist, Z. L. Wang, T. G. Schaaff,

R. L. Whetten

Porous spherical particles of ZnS nanocrystallites-M. Arnold, Z. L. Wang, S. M. Scholz, R. Vacassy,

P. Stadelmann 718

Structural stability of nanocrystalline NiAl-T. Chen, J. M. Hampikian, N. N. Thadhani, Z. L. Wang 720

The experimental accuracy of lattice spacing determination on small metal particles in commercial catalysts-

S.-C. Y. Tsen, P. A. Crozier, J. Liu

Transmission electron microscopy studies of Pd encapsulation by ceria-zirconia oxides-J. C. Jiang, X. Q. Pan,

G. W. Graham, R. W. McCabe, J. Schwank

Microstructural analysis of disordered and ordered mesoporous silica films-C. A. Drewien, Y. Lu,

C. J. Brinker, R. Ganguli, M. T. Anderson

Ordered assembling of size and shape selected nanocrystals-Z. L. Wang

Self-assembled and micro-patterned mesoscopic thin films-N. Yao, M. Trau, N. Nakagawa, I. A. Aksay 730

Growth mechanism of Ag nanocrystal supercrystals-S. A. Harfenist, Z. L. Wang, I. Vezmar, M. M. Alvarez,

R. L. Whetten

Studies of hexagonal Pt and Au nanocluster superlattices-P. Newcomer Provencio, J. E. Martin, J. G. Odinek,

J. P. Wilcoxon

Self-assembled cobalt oxide nanocrystals with tetrahedral shape-J. S. Yin, Z. L. Wang ……................................. 736

Monalayer arrangement of Pt nanoparticles-T. C. Green, J. M. Petroski, Z. Wang, M. El-Sayed ........................... 738

Nano-characterization of industrial heterogeneous catalysts_J. Liu, J. R. Ebner ..................................................... 740

Effects of cation promoters in selective catalyzation of N-butane-P. L. Gai, K. Kourtakis ................................... 742

Energy-filtered imaging of zirconia pillars in montmorillonite-P. A. Crozier, M. Pan, C. Bateman, J. J. Alcaraz,

J. S. Holmgren

Kinetically controlled growth and shape formation mechanism of platinum nanoparticles-J. M. Petroski,

Z. L. Wang, T. C. Green, M. A. El-Sayed

In situ oxidation and reduction of small Pd particles on silica-P. A. Crozier, R. Sharma

Electron holography and digital imaging for analysis of nanostructured materials-L. F. Allard, E. Voelkl,

A. K. Datye, A. H. Carim

Selected reflection imaging of nanostructured materials-Y. Liu, D. J. Sellmyer

$\mathrm{Cu}$ Nanoparticle formation: Copper redistribution during $\mathrm{NaCl}$ solution corrosion of $\mathrm{Al}-\mathrm{Cu}-\mathrm{Mg}$ alloys-

R. G. Ford, R. W. Carpenter, K. Sieradzki 
Z-contrast scanning transmission electron microscopy of nanometer-scale coated particulate materials-

H. J. Gao, Y. Yan, J. Fitz-Gerald, D. Kumar, R. K. Singh, S. J. Pennycook ..................................................... 756

Microanalysis of alloy nanoparticles-J. H. J. Scott

\section{SPATIALLY-RESOLVED CHARACTERIZATION OF INTERFACES IN MATERIALS}

Complex atomic-scale structures in solids by a combination of theory and microscopy-S. T. Pantelides, S. J.

Pennycook, M. F. Chisholm, A. Maiti, Y. Yan, F. Reboredo, M. Ferconi

Atomic structure of interfaces: Link of atomistic calculations with high resolution electron microscopy-

V. Vitek

Monte Carlo simulation of solute-atom segregation at grain boundaries in single-phase binary face-centered

cubic alloys-D. N. Seidman, J. D. Rittner, D. Udler

Core level shifts and grain boundary cohesion-D. A. Muller

Bonding and stability of metal/ceramic interfaces-U. Alber, R. Schweinfest, M. Rühle

Interfacial solute-atom segregation: An atomic-scale phenomenon with implications for the oxidation kinetics of

Pt-Al alloys-E. C. Dickey, K. B. Alexander, B. A. Pint

The measurement of light element segregation using EDS and EELS-J. T. Busby, E. A. Kenik, G. S. Was

Grain boundary dislocations and stacking defects in the 9R phase at an incoherent twin boundary in copper-

D. L. Medlin, G. H. Campbell, C. B. Carter

Investigating $\mathrm{Ca}$ segregated to a grain boundaries in $\mathrm{MgO}$ using multiple scattering analysis of electron energy

loss spectra-J. P. Buban, J. Zaborac, H. Moltaji, G. Duscher, N. D. Browning

Interface characterization of metallized CVD diamond-E. S. K. Menon, M. Saunders, I. Dutta

Microanalysis of $\mathrm{CaWO}_{4}$ and $\mathrm{ErTaO}_{4}$ coatings in oxide fiber reinforced alumina matrix composites-S. T. Kim,

V. P. Dravid, S. Sambasivan, R. W. Goettler

Local dielectric function of biogenic and geological polymorphs of $\mathrm{CaCO}_{3}$ via transmission EELS-K. S. Katti,

D. Frech, M. Qian, M. Sarikaya

Quantitative HRTEM of twin boundaries in compound semiconductors and metals using non-linear leastsquares methods- -D. Cohen, G. H. Campbell, W. E. King, C. B. Carter

Determination of rigid-body lattice translations across antiphase and twin boundaries in compound semiconductors-D. Cohen, D. L. Medlin, C. B. Carter

Atomic structures of inversion domain boundaries and dislocations in sintered AlN-Y. Yan, M. F. Chisholm,

S. J. Pennycook

Investigating atomic scale structure-property relationships at grain boundaries-N. D. Browning, H. O. Moltaji,

E. M. James, S. Stemmer, J. P. Buban, J. Zaborac

Microstructure of Josephson junctions: Effect on supercurrent transport in YBCO grain boundary and barrier

layer junctions-K. L. Merkle, Y. Huang

Bandstructure near misfit dislocations in Si quantum wells-P. E. Batson

In situ electron holography of grain boundary Schottky barrier dynamics in $0.5 \mathrm{wt} \% \mathrm{Nb}$ doped $\mathrm{SrTiO}_{3} 36.8^{\circ}$

symmetric tilt bicrystals-K. D. Johnson, V. P. Dravid

HREM characterization of magnetic tunnel junctions and discontinuous multilayers-D. J. Smith, F. Ge,

C. L. Platt, S. Sankar, A. E. Berkowitz 


\section{DEVELOPMENTS IN MEASURING POLYMER MICROSTRUCTURES}

Dose-rate dependence of radiation damage in polymers-R. F. Egerton, I. Rauf 800

Dose limited resolution-D. Van Dyck, A. J. den Dekker, J. Sijbers, E. Bettens

Effects of fast secondary electrons on spatially-resolved low-loss EELS of polystyrene-K. Siangchaew,

M. Libera

Morphology study of polystyrene-polybutadiene-polycaprolactone (PS-b-PB-b-PCL), polybutadienepolycaprolactone (PB-b-PCL), and polystyrene-polycaprolactone (PS-b-PCL) semicrystalline block copolymers-G. Kim, C. L. Jackson, F. V. Gyldenfeldt, V. Balsamo, M. Libera, R. Stadler, C. C. Han 806

Quantitative chemical speciation of multi-phase polymers using zone plate $\mathrm{x}$-ray microscopy-A. P. Hitchcock,

S. G. Urquhart, H. Ade, E. G. Rightor, W. Lidy 808

Profiling PVP/PS homopolymer interfaces using core-loss electron energy-loss spectroscopy-K. Siangchaew,

P. Prayoonthong, M. Libera

Quantitation of the lateral orientational order in poly(p-phenylene terephthalamide) fibers with $\mathrm{x}$-ray linear dichroism microscopy-A. P. Smith, A. Garcia, H. Ade

Field emission scanning electron microscopy studies of industrial polymers: A survey-E. F. Osten,

M. S. Smith

Analysis of the spatial variation of crosslink density in superabsorbent polymers-S. G. Urquhart, H. W. Ade,

G. E. Mitchell, L. Wilson, E. G. Rightor, M. Dineen, A. P. Hitchcock, U. Neuhaeusler

TEM studies of single and double microdomain layers of block copolymer-N. Yao, M. Park, C. Harrison,

D. H. Adamson, P. M. Chaikin, R. A. Register

In situ TEM study of inert fillers in liquid environment-W.-A. Chiou, Y.-C. Lee, A. Ishikawa, H. Konishi,

K. Fukushima, D. F. Shriver

Atomic force microscopy and related techniques: Introduction, instrumentation and application to polymeric

materials-I. H. Musselman

Scanned-probe microscopy of elastomer blends: Morphology and mechanical properties-M. P. Mallamaci ........ 824

The morphology of carboxylated composite latex and latex film-O. L. Shaffer, M. W. Sandor, M. S. El-Aasser

Quantitative thickness mapping of dewetting polymer bilayers-D. A. Winesett, H. Ade, A. P. Smith,

M. Rafailovich, S. Sokolov, D. Slep

The Hayashi-Nishi method for measurement of mixing: Computer-generated morphologies and impact-

modified polymers-M. R. Tant, D. B. Calvert, P. S. Wehner 830

Morphology of silicone/organic blends- $\mathrm{H}$. Zhang, W. Chen

\section{MICROSCOPIC ANALYSIS OF NATURAL FIBERS}

Scanning electron microscopy of various natural textile fibers-G. Buschle-Diller

Automating analysis of fibrous materials-R. R. Bresee, Z. Yan

Investigation of the fracture of resinated single wood fibers in an environmental scanning electron microscope

(ESEM)-A. Egan, S. Shaler

Microscopic examination of native and modified cotton fibers-W. R. Goynes 
Microscopical procedures for investigating natural textile fibers-E. K. Boylston

Mid-infrared, Raman and NMR imaging of flax-D. S. Himmelsbach, S. Khalili, G. R. Gamble, D. E. Akin ....... 844

UV absorption microspectrophotometry and histochemistry of flax and kenaf-D. E. Akin

\section{SPECIMEN PREPARATION}

A novel technique to determine platelet deposition on an experimental nylon membrane using LVSEM and

TEM-M. A. Murphy, J. P. DiOrio

Uncoated LVSEM and imaging TOF-SIMS of unfixed, plunge frozen, freeze dried, fungal and plant materials-

E. J. Basgall, N. Winograd

An en bloc staining protocol improves the preservation of lamellar bodies in alveolar type II epithelial cells for transgenic mice expressing modified pulmonary surfactant protein B-C.-L. Na, D. C. Beck, J. S. Breslin,

S. E. Wert, T. E. Weaver

Microwave processing of cell monolayers in situ for post-embedding immunocytochemistry with retention of ultrastructure and antigenicity-V. J. Madden

The effect of focused ion beam (FIB) specimen geometry on $\mathrm{x}$-ray fluorescence during energy dispersive $\mathrm{x}$-ray spectroscopy (EDS) analysis in the transmission electron microscope (TEM)-D. M. Longo, J. M. Howe,

W. C. Johnson

Material dependence of sputtering behavior during focused ion beam milling: A correlation between Monte Carlo based simulation and empirical observation-B. I. Prenitzer, L. A. Giannuzzi, S. R. Brown,

R. B. Irwin, T. L. Shofner, F. A. Stevie

Comparison of focused ion beam and conventional techniques on TEM specimen preparation of metal-ceramic interfaces-A. Ramirez de Arellano López, W.-A. Chiou, K. T. Faber

Cross-section TEM sample preparation for copper/low-K composite stacks by ion milling-B. Foran,

F. Shaapur, V. Blaschke

A new approach for cross-sectioning SEM specimens of semiconductors by broad-ion beam milling-K. Ogura,

R. Alani

The small angle cleavage technique for XTEM sample preparation-S. D. Walck, J. P. McCaffrey

Preparation of thin sections of $\left(\mathrm{Zn}_{\mathrm{x}} \mathrm{Cd}_{y}\right)$ S fine particles by an ultramicrotome-S. H. Ahn, G. S. Park,

N. R. Ahn

TEM specimen preparation for display materials of vacuum fluorescent displays-T. Dolukhanyan, C. Sung,

S. Ahn, J. Lee

Plasma cleaning for electron microscopy-T. C. Isabell, P. E. Fischione

\section{TEM SPECIMEN PREPARATION IN THE PHYSICAL SCIENCES}

The basics of microtomy for materials science microscopy-T. Malis

Tutorial: TEM specimen preparation in the physical sciences-tripod polishing and ion milling-

R. Anderson 


\section{AFM AND OTHER SCANNED PROBE MICROSCOPIES}

AFM and other scanned probe microscopies tutorial-P. E. Russell, A. D. Batchelor 878

\section{DECONVOLUTION OF BIOLOGICAL IMAGES FOR 3D LIGHT MICROSCOPY- CONFOCAL \& WIDEFIELD}

Deconvolution in 3-D microscopy: Applications and limitations-P. J. Shaw 880

Blind deconvolution of low and high signal-to-noise 3-D images of fluorescent subcellular structures-B. Rajwa,

J. Czyz, J. Dobrucki 882

Wide-field deconvolution for time-lapse 3D microscopy of cell locomotion: The good, the bad and the artifactual-J. G. McNally

Convolution and deconvolution for 3D imaging of cell physiology-L. M. Loew, M. Sapia, J. Schaff 884 886

\section{MINIATURIZED ARTIFICIAL MACHINES IN BIOLOGY}

Patterning of surface chemistry and topography for biological applications-H. G. Craighead, R. C. Davis,

M. Foquet, M. Isaacson, C. James, S. Turner, L. Kam, J. N. Turner, W. Shain, G. Banker 888

Nanobiotechnology: Biological applications of nanofabrication-J. N. Turner, W. Shain, D. H. Szarowski,

L. Kam, H. C. Craighead, M. Isaacson, S. Turner, R. Davis, C. James, G. Banker 890

Optimization of microfluidics for genetic analysis-P. M. St. John, K. Connell, T. M. Woudenberg,

M. Deshpande, J. R. Gilbert

\section{INSTRUMENTATION: HOW TO CHOOSE IT AND USE IT}

Scanned probe microscopy (AFM, et al.): How to choose and use-P. E. Russell, A. D. Batchelor 894

Choosing a scanning electron microscope-W. A. Lamberti, P. M. Brady

Choosing a suitable ultramicrotome, associated equipment and the proper laboratory environment for operation of the system-J. J. Bozzola

The confocal microscope: How to choose it and use it-J. A. Drazba 900

Designing an electron microscopy facility: Step by step procedure--J. A. Murphy 902

\section{A TECHNOLOGISTS' FORUM SPECIAL TOPIC PRESENTATION}

Fixing and embedding "difficult" biological material--H. H. Mollenhauer

The importance of optimizing operational procedures and calibrations in materials characterization using an analytical electron microscope-C. J. Echer 


\section{APPLICATIONS AND METHODS OF VASCULAR CORROSION CASTING- THE 3-DIMENSIONAL MICROVASCULATURE OF TISSUES}

Current applications and methods of microvascular corrosion casting: A review-A. Lametschwandtner,

H. Aichhorn, B. Minnich

The pulmonary circulation in health and disease-S. Aharinejad, D. E. Schraufnagel ............................................. 910

Vascular corrosion casting: Physiological considerations_K. R. Olson ............................................................ 912

Some simple quantitative applications of vascular corrosion casting-F. E. Hossler ............................................... 914

Corrosion casting in the reproduction of the micro-surface topography of fibrillar collagen-P. A. Sims, R. M.

Albrecht

Microvascularization of the uterine tube in the rabbit (Oryctolagus cuniculus) - R. P. Chopard, I. Watanabe,

C. I. Conegero

Corrosion cast demonstration of tongue vasculature of normal Wistar rats-M. C. K. Makiyama, I. Watanabe,

R. P. Chopard, M. M. Iyomasa, C. I. Mizusaki, R. A. Lopes

\section{BIOMATERIALS}

Using correlative microscopy in the study of biological-biomaterial interactions- $\mathrm{R}$. M. Albrecht

Shear and substrate dependent changes in fibrinogen and von Willebrand factor studied by atomic force

microscopy-R. E. Marchant, P. S. Sit, M. Raghavachari, C. A. Siedledcki

AFM and fractal analysis of biomaterial microtopography-S. Jo. T. Li, K. Park

A novel approach for characterisation of adhesive tooth-biomaterial interfaces by AFM-B. Van Meerbeek,

Y. Yoshida, J. Snauwaert, L. Hellemans, P. Lambrechts, G. Vanherle, K. Wakasa, D. H. Pashley

Use of polarized light microscopy to measure internal strains of collagenous tissues-I. Vesely

Morphological characterization of a sustained-release drug implant by scanning electron microscopy, polarized

light microscopy and image analysis-J. P. Neilly, J. S. Deng, J. L. House, J. A. Fagerland

Quantification of bone formation on calcium phosphate ceramic thin film, in vitro by tetracycline labelling-

J. E. Davies, F. Krasnoshtein, L. Hryhorenko, D. Sindrey

Bone formation by human oseoblasts on implant materials-G. Gronowicz, M. Ahmad

Characterization of titanium alloy particulates to study the in vitro release of inflammatory mediators by human peripheral blood monocytes-B. J. Darien, P. Sims, T. Robinson, P. Manley, R. Albrecht

Nanoscale correlation of structure and mechanical properties of a human tooth-H. Fong, M. Sarikaya

Effect of "stress-absorbing" dentin adhesives on the interaction of composites with human dentin-an SEM

study-C. Francci, A. V. Ritter, J. Perdigão, B. T. Rosa

\section{IMAGING OF MACROMOLECULAR COMPLEXES}

Cryo-electron microscopy of Aura viruses-W. Zhang, N. H. Olson, B. R. McKinney, R. J. Kuhn, T. S. Baker ... 
Cryo-electron microscopy and image reconstruction of $P B C V-1$, an algal virus with $T=169$, icosahedral lattice symmetry-X. Yan, N. H. Olson, J. L. Van Etten, T. S. Baker

CTF corrected structure of the closed-state calcium release channel-S. Ludtke, I. Serysheva, S. L. Hamilton,

W. Chiu

Formation of proteasome-PA700 complexes directly correlates with activation of peptidase activity-G. Adams,

B. Crotchett, C. Slaughter, G. DeMartino, E. Gogol 952

On the unique structural organization of the Saccharomyces cerevisiae pyruvate dehydrogenase complex-

J. K. Stoops, Z. Hong Zhou, J. P. Schroeter, S. J. Kolodziej, R. H. Cheng, T. S. Baker, D. L. B. McCarthy,

M. A. Yazdi, C.-Y. Maeng, L. J. Reed

\section{CHAMBERS AND CHANNELS: FUNCTIONAL CONNECTIONS IN MULTIPROTEIN COMPLEXES STUDIED BY SINGLE CHAMBERS AND CHANNELS}

Nuclear pore transport: Insight in situ-U. Aebi, D. Stoffler, B. Feja, K. Goldie

FEISEM, form and function in the nuclear pore complex-T. D. Allen, G. R. Bennion, S. A. Rutherford,

E. Kiseleva, M. W. Goldberg

Structural studies of translocation channels: The nuclear pore complex and the translocon-Q. Yang,

J.-F. Ménétret, I. V. Akey, K. Plath, T. A. Rapoport, C. W. Akey

The ribosome-three-dimensional structure and ligand-binding studies-J. Frank, P. Penczek, A. Malhotra,

I. Gabashvili, R. Grassucci, A. Heagle, S. Srivastava, N. Burkhardt, R. Jünemann, K. H. Nierhaus,

R. K. Agrawal

Molecular architecture of ribonucleoprotein vaults-P. L. Stewart, L. H. Rome, L. B. Kong 964

High resolution epitope mapping of the hepatitis B virus capsid by cryo-electron microscopy-J. F. Conway,

N. Cheng, A. Zlotnick, S. J. Stahl, P. T. Wingfield, D. M. Belnap, A. C. Steven 966

The ryanodine receptor/calcium release channel and its interaction partners-T. Wagenknecht, M. Samso 968

3D reconstruction of mannosidase II from single particle distributions: Noise reduction approaches for higher resolution-F. P. Ottensmeyer, A. B. Fernandes, M. Timmer, J. Kroft, K. Varga, K. W. Moremen 970

Structure of wild type yeast RNA polymerase II and location of RPB4 and RPB7-G. J. Jensen, G. Meredith,

D. A. Bushnell, R. D. Kornberg

Cytomegalovirus capsid structure and tegument binding-A. C. Steven, W. Gibson, N. Cheng, B. L. Trus 974

Cryo-electron microscopy and image processing methods for studying the ribonucleoprotein vault-L. B. Kong,

L. H. Rome, P. L. Stewart 976

\section{PROTEOLYSIS: A VERSATILE BIOLOGICAL CONTROL MECHANISM}

Protein unfolding and degradation by the CLP family of proteases-M. Kessel, F. Beuron, F. Booy, E. Kocsis, M. Maurizi, A. Steven

Macromolecular assemblies designed for controlled proteolysis-J. Walz, A. J. Koster, T. Tamura,

W. Baumeister 
Formation of proteasome-PA700 complexes directly correlates with activation of peptidase activity-E. Gogol,

G. Adams, B. Crotchett, C. Slaughter, G. DeMartino

Proteolytic control of bacteriophage HK97 capsid maturation.--R. L. Duda, J. F. Conway, N. Cheng,

A. C. Steven, R. W. Hendrix

On the structure-function relationships of the unique proteinase inhibitor human $\alpha_{2}$-macroglobulin- -

J. K. Stoops, S. J. Kolodziej, U. Qazi, N. J. Nolasco, P. G. W. Gettins, D. K. Strickland 986

\section{RECENT ADVANCES IN LABELING TECHNIQUES}

Strategies insuring the optimal use of IgG or $\mathrm{FAB}^{\prime}$ fragments covalently bound to $1.4 \mathrm{~nm}$ nanogold ${ }^{\mathrm{TM}}$ in immunogold labeling procedures-C. A. Ackerley, A. Tilups, L. E. Becker

Fluoronanogold: An efficient labeling reagent for immunocytochemistry-J. M. Robinson

Dual-labeled probes for fluorescence and electron microscopy-R. D. Powell, C. M. R. Halsey, E. Gutierrez,

J. F. Hainfeld, F. R. Furuya

Molecular cloning and expression of 6HIS-GFP reporter gene for fluorescent and electron spectroscopic imaging-M. Malecki, S. Sanchez, P. Skowron, G. Case

New advances in super-sensitive DNA-, RNA- and antigen detection: Combination of labeled tyramides with nanogold-silver staining (NGSS)-G. W. Hacker, C. Hauser-Kronberger, I. Zehbe, H. Su, R. Tubbs

Correlative instrumental neutron activation analysis, LM, and TEM to track in vivo distribution of colloidal gold spheres in BALB/c mice-J. F. Hillyer, R. M. Albrecht

\section{DETECTION AND APPLICATION OF GREEN (AND OTHER COLORED) FLUORESCENT PROTEINS}

Properties and applications of EGFP, enhanced color variants of GFP, and unstable derivatives of GFP-

P. A. Kitts, X. Li, D. W. Piston, R. Chervenak, S. R. Kain 1000

Fluorescent antenna proteins from the bioluminescent bacteria-J. Lee

Quantitative imaging of the green fluorescent proteins-D. W. Piston, G. H. Patterson, S. M. Knobel 1004

Green fluorescent protein as a non-invasive probe of viscosity and $\mathrm{pH}$ in cell cytoplasm and organelles-

A. S. Verkman 1006

GFP fusions for fluorescence detection of $\mathrm{Ca}^{2+}$ and $\mathrm{Ca}^{2+}$-calmodulin in living cells-A. Persechini 1008

Use of green fluorescent protein (GFP)-chimeras to study cytoskeletal assembly and dynamics-

G. G. Gundersen, A. Mikhailov, J. L. Martys, L. Ho, R. K. H. Liem, L. Smelinov, E. E. Marcantonio 1010

Efficient, retroviral-mediated expression of GFP fusion proteins as inhibitors of intracellular signal transduction

pathways: A case study-T. J. Murphy, X. Wang 1012

GFP-tagged protein domains as tools to study localized second messenger function in living cells- $\mathrm{T}$. Meyer,

E. Oancea, T. Stauffer, M. N. Teruel

Microscopic investigations of the infection process of Choristoneura fumiferana nucleopolyhedrovirus in the spruce budworm-A. J. Brownwright, J. W. Barrett, T. R. Ladd, M. Primavera, S. S. Sohi, B. M. Arif,

A. Retnakaran, S. R. Palli 1016 


\section{DYNAMICS OF CELLULAR MEMBRANE TRAFFIC}

Light microscopy beyond the wavelength limit: Methods for characterizing cell surface membranes-

M. Edidin, A. K. Kenworthy, L. Gheber 1018

Optical measurements of presynaptic function: What keeps vesicle traffic going?-T. A. Ryan .............................. 1020

Dynamin mediates membrane vesiculation—S. M. Sweitzer, J. E. Hinshaw ........................................................ 1022

Characterization of endocytic pathways by quantitative fluorescence microscopy-F. R. Maxfield, R. N. Ghosh,

W. G. Mallet, T. T. Soe, P. L. Leopold, L. Cohen-Gould, S. Mayor, S. Mukherjee, X. Zha, T. E. McGraw ..... 1024

Transport through the secretory pathway: Observations of cargo and peripheral coat proteins-J. F. Presley,

N. B. Cole, J. Lippincott-Schwartz 1026

Fluorescent and electron microscopic studies suggest that confronting cisternae arise from nuclear envelope in

mitotic cells-J. R. Palisano, J. L. Thacker, C. S. Piromalli, A. M. Morrison, J. E. Tate 1028

Electron microscopy of bound polysomes on in vitro rough endoplasmic reticulum prepared by

cryohomogenization-A. K. Christensen 1030

Immunoperoxidase labeling demonstrates an early divergence of Chlamydia trachomatis from the endosomal-

lysosomal pathway-E. R. Fischer, M. A. Scidmore-Carlson, T. Hackstadt

Nature of ADH-induced endosomes in toad urinary bladder granular epithelial cells-A. J. Mia, L. X. Oakford,

A. Dibas, T. Yorio 1034

\section{CHEMOTHERAPEUTIC AGENTS THAT AFFECT MICROTUBULES: MECHANISMS OF RESPONSE AND CHEMOTHERAPEUTIC AGENTS AND MICROTUBULES}

Apoptosis and resistance to anti-microtubule agents- $M$. C. Willingham 1036

Neutrophil microtubules display unusual properties and are highly sensitive to taxol-J. M. Robinson,

D. D. Vandré 1038

Molecular regulation of taxane-induced apoptosis-K. Bhalla 1040

Taxol-induced apoptosis may occur via a signaling pathway independent of microtubule bundling and cell cycle arrest-W. Fan, M. C. Miller III, L. Cheng, M. C. Willingham 1042

\section{APPLICATION OF CLASSICAL AND NOVEL MICROSCOPY TO TISSUE INJURY AND INFECTIOUS DISEASE PATHOGENESIS}

Applications of correlative microscopy in diagnostic and investigative pathology—D. N. Howell, S. E. Miller ..... 1044 Molecular pathology_implications for diagnosis and pathogenesis of infectious diseases-S. R. Zaki .................. 1046 Immune system activation after cisplatin or "poly-plat" treatment: An in vivo study-D. J. Telgenhoff,

S. K. Aggarwal 1048

Towards understanding the structural requirements for endogenous transcription in rotavirus-J. A. Lawton,

M. K. Estes, B. V. Venkataram Prasad 1050 
Negative stain electron microscopy ... a valuable diagnostic method in a molecular probe diagnostic world-

C. D. Humphrey, S. S. Monroe, R. I. Glass

Ultrastructural characterization of virus-like particles produced by a recombinant baculovirus expression

vector-A. J. Wasserman, H. Wang, G. Clark, J. R. Megill, S. K. Durham 1054

The application of microscopy and other imaging techniques to the study of disease in the fetus-

W. R. Blackburn, J. Hudson, N. R. Cooley, Jr. 1056

Microvascular architecture of the lingual papillae in rabbits--T. S. Masuko, B. König Jr., B. R. Schmidt 1058

\section{PATHOLOGY}

Ultrastructural changes in hepatocellular rough endoplasmic reticulum in rats given a pyrimidine derivative--

B. E. Maleeff, S. J. Newsholme, T. K. Hart 1060

Morphometry of liver lesions in an ultrastructural pathology study-A. Singh, W. P. Ireland, I. Chu 1062

A morphometric analysis of early effects of ethanol on hepatocyte organelles from Peromyscus maniculatus-

J. T. Ellzey, J. P. Drake, L. Dader, P. Boentges 1064

Centrosome proliferation in the human androgen-responsive LNCaP and the androgen-independent DU145

prostate cancer cell lines-H. Schatten, M. Ripple, R. Balczon, M. Taylor, M. Crosser 1066

Sertoli cell adhesion molecules: Comparative expression of L-selectin and other CAMs in primary cells and

immortalized Sertoli cell lines-A.-M. Broome, C. F. Millette 1068

Prevention of changes in endothelial cells cultured in high glucose-C. A. Taylor, Z. Imdad, J. Puchalski,

S. Lemley-Gillespie, A. K. Mandal 1070

Effects of nitric oxide on monocrotaline induced right ventricular hypertrophy and lung mast cell hyperplasia in rats-K.-S. Hung, W. H. Duncan 1072

Nitric oxide synthase in diabetic retinopathy in the BBZ/Wor rat: An immunocytochemical study-E. A. Ellis,

M. B. Grant, D. L. Guberski 1074

The effects of cigarette smoke on porcine airway epithelium-D. D. Morgan, A. G. Moss 1076

Molecular pathologic studies on the mechanisms of radiation-induced hematopoietic cells apoptosis and the recovery in mouse bone marrow-D. W. Wang, R. Y. Peng, C. Q. Xiong 1078

Pericyte ultrastructural pathology in autoimmune inflammatory myopathies-H. J. Finol, A. Márquez,

M. Pulido-Méndez, B. Müller, I. Montes de Oca, P. Tonino 1080

Muscle biopsy: Use of cryosections, histochemistry, and electron microscopy for diagnosis-C. L. Hastings,

Y. M. Jones, R. E. Mrak 1082

Ultrastructural localization of CD34 in soft tissue tumors-J. M. Minda, T. J. Lawton, M. van de Rijn 1084

Ultrastructural diagnosis of a pheochromocytoma at autopsy-S. Siew, B. Newton 1086

Ion-channel activator-induced ultrastructural changes in the dog retina-J. R. Megill, T. M. Monticello,

A. J. Wasserman, W. A. Kelly, S. K. Durham 1088

Macrophage targeted photodynamic regulation of wound healing-M. Coleno, V. P. Wallace, B. J. Tromberg,

T. Hasan

Tissue response to bone substitute materials supporting dental implants--K. E. Krizan, D. Lew, T. Rubey,

J. C. Keller 


\section{CYTOCHEMISTRY (LIGHT AND ELECTRON HISTOCHEMISTRY)}

Quantitation of peroxisome proliferation using silver enhanced immunogold labeling on glycol methacrylate (GMA) sections-G. D. Gagne, A. H. Illi, D. Hickman, J. A. Fagerland 1094

Subcellular localization of an oncoprotein using immunofluorescence, confocal imaging and immuno electron microscopy-K. Murti, C. Caslini, P. H. Domer, S. J. Korsmeyer, J. Boer, G. Grosveld, A. T. Look 1096

Visualization of the transport pathways of high density lipoproteins across the endothelial cells in the rat arteries-H. H. Lin, W. T. Chao, V. C. Yang 1098

Electron microscopic immunolocalization of basic fibroblast growth factor-like molecules in capillary endothelial cells-R. G. Aktas, R. J. Kayton

Ultrastructural distribution of basic fibroblast growth factor-like molecules in peripheral nerves- R. J. Kayton, R. G. Aktas

Acid phosphatase activity in spiral ganglion neurons of C57BL/6 mice-G. M. Cohen 1104

Age- and condition-related changes in levels of neuron specific enolase in spiral ganglion neurons of C57BL/6 mice-G. M. Cohen 1106

Demonstration of Z-RNA in the dog eye lens epithelium (germinative zone)-C. E. Gagna, J. H. Chen, H. R. Kuo, W. C. Lambert 1108

Catalase gene therapy in experimental optic neuritis: Immunocytochemistry study-X. Qi, J. Guy 1110

Ciliogenesis and axonemal dynein expression in human airway epithelium cultured in an air/liquid interface environment-J. L. Carson, W. Reed, L. Brighton, T. M. Gambling, A. M. Collier

Microwave-assisted immunoelectron microscopy of skin-J. P. Petrali, K. R. Mills 1114

Investigation of DNA loop domains using fluorescent in situ hybridization (FISH) and epifluorescence microscopy-A. V. Klaus, S. McCarthy, J. McCarrey, W. S. Ward 1116

Immunocytochemical localization of myosin light chains in the abdominal superficial flexor muscles of the American lobster, Homarus americanus-L. D. Brown, M. E. Cantino

Suppression of gastrin production after cisplatin treatment in rats-Y. Wang, S. K. Aggarwal 1120

Immunocytochemical analysis of murine peritoneal macrophages treated with "poly-plat", an in vitro and in vivo study-H. J. Muenchen, S. K. Aggarwal

Gamma tubulin is localized to a new organelle, the multivesicular aggregate, in mammalian oocytesP. G. Calarco

Confocal laser scanning microscopy of hamster cerebellum using FM4-64 as intracellular staining-O. Castejón, P. Sims

Investigation of DNA loop domains using fluorescent in situ hybridization (FISH) and epi-fluorescence microscopy-A. V. Klaus, S. McCarthy, J. McCarrey, W. S. Ward

\section{BIOLOGICAL ULTRASTRUCTURE/MICROBIOLOGY}

Environmental scanning electron microscopy (ESEM) study of sea urchin embryos after deciliation with chloral hydrate-H. Schatten, A. Chakrabarti

The centriole-centrosome complex is affected by microgravity during cell division and in cilia of sea urchin embryos: Results from space flight experiments-H. Schatten, A. Chakrabarti, M. Taylor, M. Crosser, K. Mitchell 
Integrated microscopy of extracellular adhesives of the marine biofouling alga Achnanthes longipes

(bacillariophyceae)-Y. Wang, B. A. Wustman, Y. Chen, C. Lavin, M. R. Gretz

High pressure freezing and freeze substitution of primitive agglutinated foraminifera-S. T. Goldstein,

E. A. Richardson 1136

EM study of isopod hemocytes-G. M. Vernon, E. J. Rappa, W. C. Murray, R. Witkus 1138

Ultrastructure of haustoria of plant pathogenic fungi-C. W. Mims, E. A. Richardson 1140

Ultrastructure of septa from the filamentous fungus Aspergillus nidulans-E. A. Richardson, M. Momany 1142

Ivermectin-induced hypertrophic changes in adult canine heartworm (Dirofilaria immitis) gut epithelium-

W. L. Steffens, J. W. McCall

Characterization of the cell surface of Perkinsus marinus, a pathogen of the Eastern oyster, Crassostrea virginica utilizing electron microscopy, light microscopy and epifluorescent microscopy-J. Neimark 1146

Taxonomic identification of Rhabdochona species found in Oncorhyncus clarki using scanning electron microscopy-D. Young, R. A. Heckmann, J. S. Gardner 1148

Size and density variation in microtriches from Bothriocephalus species found in Cyprinus carpio from Lake

Powell, Utah-I. Bingham, L. Bingham, R. A. Heckmann, J. S. Gardner

Analysis of endocytosis and food plaquette formation in the ciliated protozoan Hyalophysa-S. C. Landers,

R. A. Treadaway

Bioremediation: Utilization of aircraft paint waste as a nutrient source by Pseudomonas sp. VM1-

J. E. Thurmond, W. N. Norton, G. T. Howard

Applications of soft x-ray and other microscopy techniques to elucidate the structure of parasitic metazoa-

W. J. Kozek, J. Brown, W. Meyer-Ilse, C. Larabell, M. Moronne 1156

Identification of papilloma-like virus particles in cell lines derived from green sea turtle (Chelonia mydas) with

fibropapilloma-Y. Lu, V. R. Nerurkar, T. M. Weatherby, R. Yanagihara 1158

Fibrinogen Kurashiki ( $\gamma$ G268E) fibrin network structure-J. P. DiOrio, M. W. Mosesson, M. Matsuda 1160

\section{DEVELOPMENTAL BIOLOGY}

High resolution immuno-electron microscopy reveals that fetal skin contains microfibrils which are

heteropolymers of fibrillin-1 and fibrillin-2-D. R. Keene, N. L. Charbonneau, B. J. Dzamba,

D. P. Reinhardt, C. C. Ridgway, R. N. Ono, L. Y. Sakai 1162

Effect of prematurity on the presence of Weibel-Palade bodies in human umbilical vein endothelial cell in situ-

N. Tabatabaei, K. H. Albertine, L. Wenhua, D. E. Lorant 1164

Temporal and spatial expression patterns of PDGF receptors in embryonic rat heart as detected through confocal

scanning laser microscopy-T. Thielen, W. Carver, D. G. Simpson, T. K. Borg, L. Terracio, R. L. Price ........ 1166 2G alters the utricular macula of chick embryos-H. Hara, C. D. Fermin Aminoglycoside damage to young rats equilibrium-H. Hara, G. Meza, B. Bohne, J. Hara, C. D. Fermin ............. 1170 A scanning electron microscopic study of adhesive pad development in the frog Phyllomedusa trinitatis-

T. A. Ba-Omar, J. R. Downie 


\section{BOTANY/PLANT PATHOLOGY}

Effect of calcium on salt tolerance of leaf epidermal cells of Ruppia maritima at high salinity-A. D. Barnabas,

R. Jagels, W. J. Przybylowicz, J. Mesjasz-Przybylowicz

Ultrastructure and elemental distribution in foliage of manganese-treated sugar maple seedlings: Comparison

of freeze-substitution fixatives-C. J. McQuattie, G. A. Schier, S. Burns, J. W. Heckman, Jr.

Unusual mitochondrial aggregation with virus in infected transgenic plants-L. Zhang, W. G. Langenberg

Pollination in Arabidopsis thaliana-K. Lennon, E. Lord

The contribution of Symbiodinium microadriaticum to the symbiosome membrane in the anthozoan host Aiptasia pallida-T. S. Wakefield, S. C. Kempf, M. A. Farmer

Amino acid composition and immunolabelling of a $42.5 \mathrm{kDa}$ protein from phloem exudate of Luffa cylindrica fruits-M. C. Wang, Y. R. Chen

On the cover: Shaded-surface view of an Aura virus particle. This reconstruction is viewed along a two-fold axis of symmetry. Small protrusions at the outermost periphery of the glycoprotein spikes are features not previously observed in other alphaviruses. From W. Zhang, N. H. Olson, B. R. McKinney, R. J. Kuhn, T. S. Baker, Cryo-electron microscopy of Aura viruses, page 946. 
https://doi.org/10.1017/S1431927600020122 Published online by Cambridge University Press 

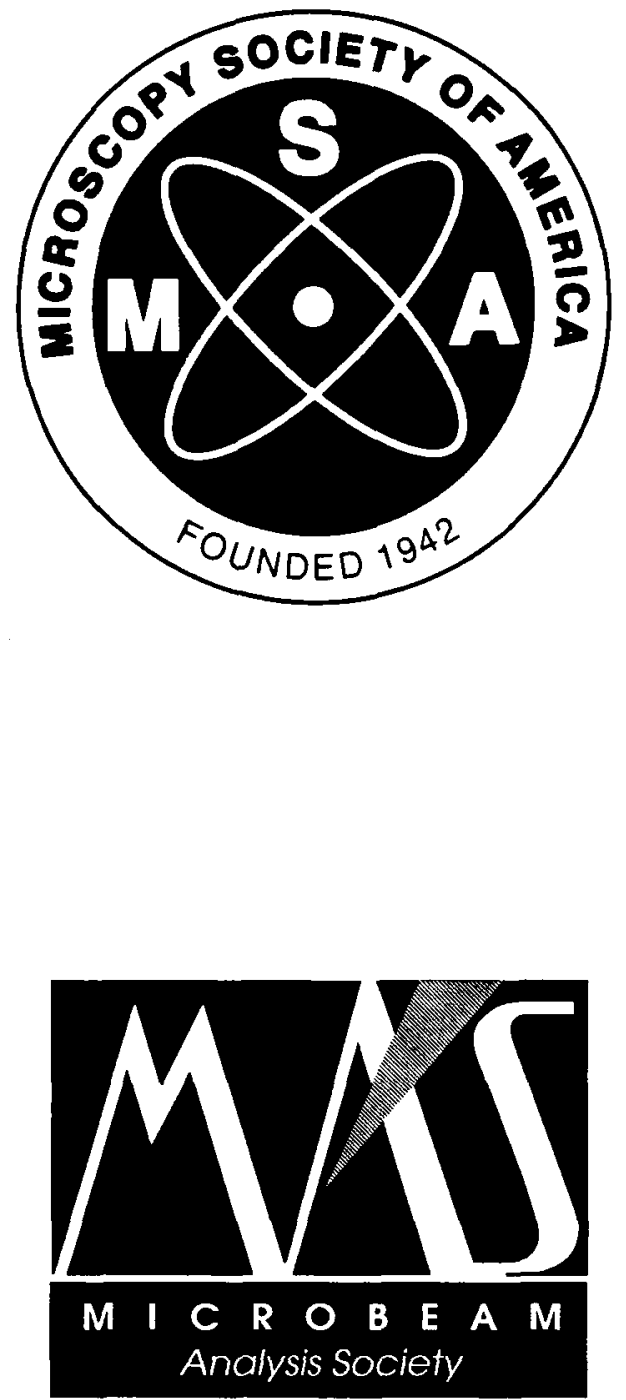